NBSIR 84-2828(R)

\title{
Functional Programming/Research Planning for High Technology Federal Office Buildings
}

U.S. DEPARTMENT OF COMMERCE National Bureau of Standards National Engineering Laboratory Center for Building Technology Washington, DC 20234

U.S. DEPAPTMENT OF COMMERCE National Bureau of Standards National Engineering Laboratory Center for Fire Research Washington, DC 20234

January 1984

Prepared for:

nublic Buildings Service

eneral Services Administration 'ashington, DC 20405 



\title{
FUNCTIONAL PROGRAMMING/RESEARCH \\ PLANNING FOR HIGH TECHNOLOGY \\ FEDERAL OFFICE BUILDINGS
}

\author{
G. E. Turner \\ J. R. Clifton \\ J. Y. Kao \\ G. E. Kelly \\ L. W. Masters \\ A. I. Rubin \\ S. T. Wu \\ S. L. Yaniv
}

U.S. DEPARTMENT OF COMMERCE

National Bureau of Standards

National Engineering Laboratory

Center for Building Technology

Washington, DC 20234

H. E. Nelson

U.S. DEPARTMENT OF COMMERCE

National Bureau of Standards

National Engineering Laboratory

Center for Fire Research

Washington, DC 20234

January 1984

Prepared for

Public Buildings Service

General Services Administration

Washington, DC 20405

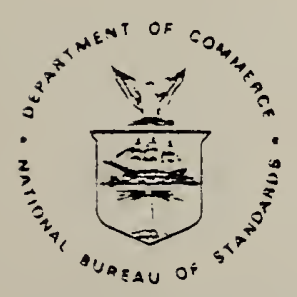

U.S. DEPARTMENT OF COMMERCE, Malcolm Baldrige, Secretary NATIONAL BUREAU OF STANDARDS, Ernest Ambler, Direc:or 



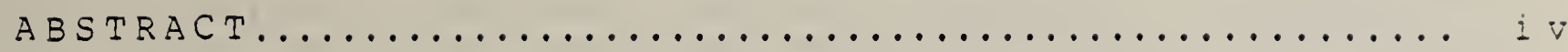

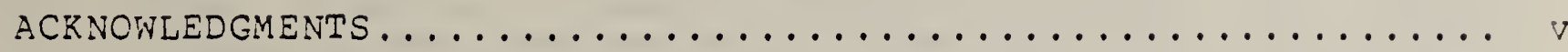

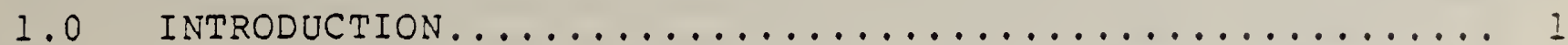

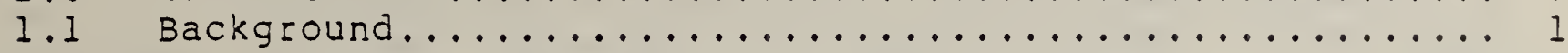

1.2 Objective and scope of the Report................. I

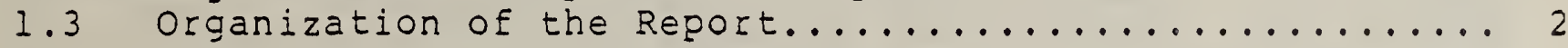

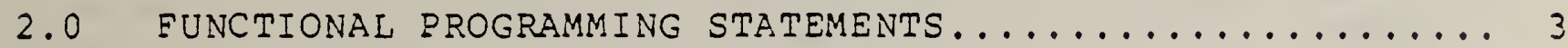

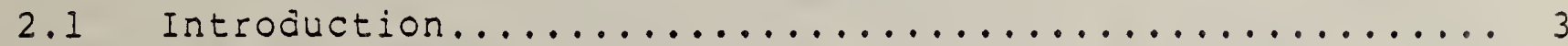

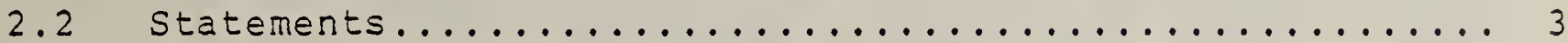

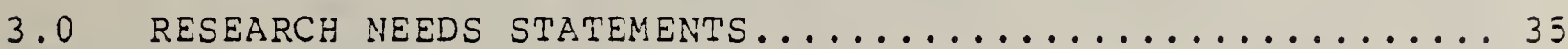

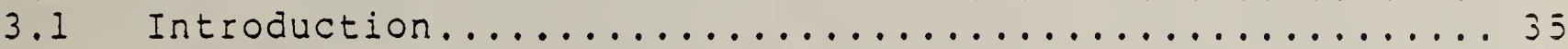

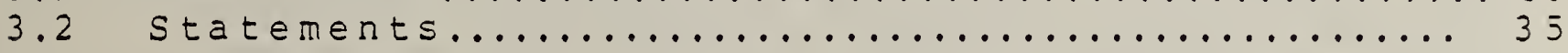

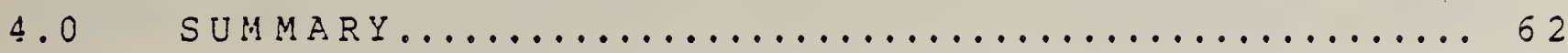




\section{ABSTRACT}

The General Services Administration (GSA), Public Buildings Service (PBS) is engaged in the development of a new design approach for Federal buildings referred to as "high technology" (high-tech). The approach emphasizes the consideration of new, emerging and innovative uses of existing technology applications in building system design, construction and operation. In order to develop design programs for high-tech building projects, there is a need for PBS to identify programing issues that address new, emerging and innovative uses of existing technologies, and there is a need for PBS to develop a plan of research in support of its high-tech design approach. Under a memorandum of understanding with GSA, the National Bureau of Standards' (NBS), Center for Building Technology (CBT) assisted PBS by providing technical support through the development of programming issues and research needs for high-tech office buildings. The programming issues and research needs developed by NBS represent the identification of programming and research topics to be considered by GSA during its programming and research planning activities. 


\section{ACRNOWLEDGMENTS}

The authors would like to express gratitude to Mr. Robert Dikkers, Dr. Richard Marshall, Mr. James Pielert, and Dr. Stephen Weber for their thoughtful reviews of the report. In addition, the authors wish to thank Ms. Anita Sweigert for her very prompt and efficient typing of the report. 


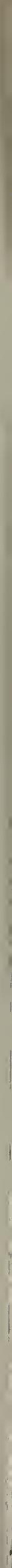




\subsection{INTRODOCTION}

\subsection{Background}

The General Services Administration (GSA), Public Buildings Service (PBS) is engaged in the development of a new design approach for Federal buildings referred to as "high technologin (nigh-tech). The new approach emphasizes the consideration of new, emerging and innovative uses of existing technology applications in building system design, construction and operation. Particular emphasis is placed on the use of automation and advanced communication technologies applicable to office work environments.

In order to develop design programs for high-tech building projects, there is a need for PBS to identify programming issues that address new, emerging and innovative uses of existing technologies. In addition, there are areas where advantages may be realized through high-tech applications but the applications are constrained or prevented because of insufficient testing and/or in-use performance data. As a result, there is a need for PBS to develop a plan of research in support of its high-tech design approach.

\subsection{Objective and Scope of the Report}

Under a memorandum of understanding with GSA, the Viaticral Bureau of Standards (NBS), Center for Building Technology (CBT) assisted PBS by providing technical support through the deveiopment of functional programming statements (FPS) and research needs (Ris) for high-tech office buildings.

The programming statements will be used by GSA as zeference injormation input to its building design programming process. A design program serves as a guide to architects, engineers and space planhers in making decisions by informing them of the perfornance goals, objectives and criteria that a building design nus neet. The research needs statements will be used by GSA as ingut co its research planning process. The research pian wi i consistoja schedule of research in support of the GSA high-tech design approach.

The programming and research needs develoged by lizs represent the identification of programming and research topics co de

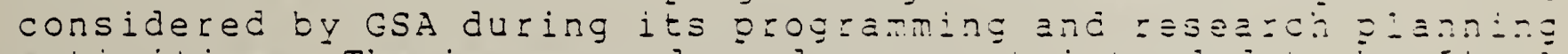
activities. The issues and needs are not intended to be inal design directives nor Einal research proposals.

The development of the programing issues consiszed oj ine iden: :-

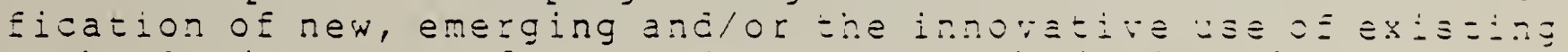

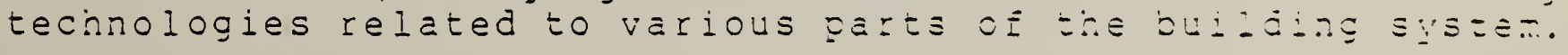


Section 2.0 contains the set of functional programming statements developed by CBT and the Center for Eire Research (CER).

The research needs were developed from constraints to or prevention of immediate application of certain of the programming issues, and from the CBT staffs' familiarity with the insufficient testing and/or lack of in-use performance data for various technologies having potential applications in Federal office buildings.

\subsection{Organization of the Report}

This report is organized in three sections:

Sectionl, the current section, provides a general introduction, including the objective and scope of the report.

Section 2 contains the functional programming statements developed by CBT and CFR staff members.

Section 3 contains the research needs statements development by CBT staff members.

Section 4 contains a summary of the report and reiterates the intended use for the statements that have been developed. 


\subsection{FONCTIONAL PROGRAMMING STATEMENTS}

\subsection{Introduction}

The functional programming statement sheets contained herein are organized according to the categories of design directives found in a GSA design program. Although no statements were developed for categories one, two and five, the complete list of cesign directive categories is as follows:

1. Bullding concept. Design decisions include overall shape and image of the building, its height, and configuration of floors, including location of the core.

2. Site development. Includes relationship of proposed design to existing structures, building placement and decisions about access and egress to buildings, locations of parking areas and planned outdoor use places, a landscape plan, and circulation issues including where people will enter the site.

3. Building infrastructure. Includes decisions about foundations, structural systems, and plenum areas within the building.

4. Building enclostre, Design decisions regarding windows, walls, insulation, vapor barrier systems, and facade treatment issues are included in this section.

5. Space al location. Decisions relate primarily to interior space planning issues and include space needs, spatial adjacencies, spatial groupings, circulation, and growth projections.

6. Building sustems. Includes ali other najor building systems: energy, HVAC, electrical and communication, i ighting, acoustics, and elevators.

\subsection{Statements}

The statements are presented on the jollowing 31 pages wit: esch statement formatted separately in a standardizec layout. 
FONCTIONAL PROGRAMMING POR BIGE TECBNOLOGY PEDERAL OPFICE BOILDINGS

\section{PONCTIONAL PROGRAMMING STATEMENTS}

PROGRAMMING ISSOE:

Base Isolation System -- Seismic Safety and Protection

Building Systems Involved:

Building Infrastructure (Foundations and superstructures)

Issue statement:

For buildings located in zones with high probable seismic risk, structures such as public office buildings should be designed to resist large lateral forces induced from strong earthquake motions. Based on current codes and standards [i], seismic design may be considered satisfactory if an earthquake causes no loss of life. Damage sustained by the building, however, may vary from minor to irrepairable.

Possible Applications:

The concept of "base isclation" has been develofec and applied to buildings. By implementing a base isolation system, the lateral design forces can be greatly reduced. This can ensure safety of the structure.

Other System Integration Requirements:

1. There may be larger relative displacements across the base isolation system than is the case for conventional design. Therefore, utility connections, electrical and mechanical ecuipment must be designed to accommodate such movements.

Constraints to Application:

1. The technology is relatively new to the building industry. Hence, it may add to the design and construction costs (even though the cost of structural members can be reduced).

2. The long-term performance of base isolation systems has not been documented [2].

3. Human response to floor vibration should also be considered [3].

Actions Necessary for Application Feasibility:

Engineering design firm(s), manufacturer(s), and contractor(s) must be selected to ensure proper design and construction cf the base isolation system. Special details for inspection, maintenance, and replacement of the components cE the system must be planned at the desicgr stage. 
Points of Contact and/or Resources:

S.T. Wu, 301-921-2198, CBT/NBS

[1] See EDS-5.
$[2]$ see RNS-1.
$[3]$ see reierenc

[3] See reierence NBS SP 474, "3uilding for Pecple," by Rúir, A. and Elcer, I., 1980. 


\section{FPS-2}

FUNCTIONAL PROGRAMMING FOR BIGB TECHNOLOGY FEDERAL

OFFICE BOILDINGS

BUNCTIONAL PROGRAMHING STATEMENTS

PROGRAMMING ISSUE:

Base Isolation Syster: -- Seismic Safety

Building Systems Involved:

Builaing Infrastructure (Structural Components)

Issue statement:

In-situ measurements are needed to verify the effectiveness of the base isolation system (when the structure is subjected to earthquake excitation or wind loads).

Possible Applications:

Measurements require installation of accelerographs on floors or foundations above and below the base isolation system. Strain gages are also required on critical structural elements.

Other System Integration Requirements:

1. These devices may be included as part of the integrated system (if selected) for the building management, e.g., for fire safety, security, and thermal'control.

Constraints to Application:

1. Cost may be the only constraint to incliding this instrumentation.

Actions Necessary for Application Feasibility:

1. Select instrumentation based on measurement capabilities, limitations, reliabilities, costs and installation details.

2. Calibrations may have to be performed periodically.

3. The locations of the measurements must be properly jetermined.

Points of Contact and/or Resources:

S. T. Wu, 301-921-2198, CBT/NBS

E. V. Leyendecker, 301-921-3471, CBT/NBS 


\section{FPS-3}

\section{PONCTIONAL PROGRAMMING POR HIGB TECENOLOGY PEDERAL ORPICE BUILDINGS}

\section{PONCTIONAL PROGRAMMING STATEMENTS}

PROGRAMMING ISSOE:

Epoxy-coated Steel Reinforcing Bars

\section{Building Systems Involved:}

Building Infrastructure (Eoundations, Structure)

Issue statement:

Steel reinforcement embedded in concrete can corrode when the concrete is infiltrated by certain inorganic salts, especially those containing chloride ions. Salt water exposures are rell known to be aggressive, greatly accelerating the corrosion of steel. Corrosion of reinforcing steel results in cracking of concrete and eventually its disintegration. Epoxy coatings have been demonstrated to effectively protect steel reinforcing bars from corrosion while not disturbing the structural integrity of the reinforced concrete.

Possible Applications:

Epoxy-coated reinforcing bars should be used in those portions of a building where its concrete may be exposed to narine environments, deicing salts, or other scurces of inorganic salts.

Other system Integration Requirements:

None.

Constraints to Application:

1. Epoxy-coated reinforcing bars may cost up to 100 percent more than uncoated reinforcing bars.

2. Only certain epoxies can be used and good quality contro? practices must be followed in coating reinforcing bars.

Actions Necessary for Application Peasibility:

Make contact with coaters who can apply appropriate epoxy coatings to steel reinforcing bars to determine cost and avaitaziliz: at specific construction sites.

Points of Contact and/or Resources:

James R. Clifton, 301-921-3458, CBT/NBS

Clifton, J.R., Beeghly, H.F., and Vethey, R.G., Nonzetallic

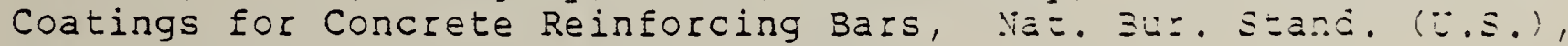
Bldg. Science Series 65, August 1975. 
Clifton, I.R., "Bond and Creep Characteristics of Coated Reinforcing Bars in Concrete," American Concrete Institute Journal, 80 (1983), 288-233. 


\section{FPS -4}

\section{PUNCTIONAL PROGRAMMING FOR BIGH TECENOLOGY PEDERAL OPFICE BOILDINGS}

\section{PONCTIONAL PROGRAMMING STATEMENTS}

PROGRAMMING ISSUE:

High-strength Concrete

\section{Building Systems Involved:}

Building Infrastructure (Foundations, structure)

\section{Issue Statement:}

High-strength foncretes with compressive strengths as high as 83 $\mathrm{MPa}$ ( $12 \times 10^{3}$ psi) are commercially available. Use of highstrength concrete facilitates innovative design and the reduction of dead-weight loading through reduced sizes of structural members.

Possible Applications:

Structural members of a building, particularly for columns in high-rise buildings.

Other System Integration Requirements:

unknown.

Constraints to Application:

1. Avallability of high-strength concrete at specific construction sites.

2. Dynamic properties of high-strength concretes have not been well characterized.

Actions Necessary for Application Peasibility:

Make contact with concrete companies to determine arailability, performance, warrantee, and cost of high-strength concrete.

Points of Contact and/or Resources:

James R. Clifton, 30l-921-3458, CBT/NBS

American Concrete Institute, 313-532-2600, Detroit, Michigan

Eroceedings, workshop on High-strength Concrete, university oz Illinois at Chicago Circle, Chicago, IL, Decerber 2-4, 1979. 


\section{FPS-5}

\section{FUNCTIONAL PROGRAMMING FOR HIGE TECENOLOGY FEDERAL OFFICE BOILDINGS}

\section{FUNCTIONAL PROGRAMMING STATEMENTS}

\section{PROGRAMMING ISSUE:}

Design Philosophy on Seismic Safety

\section{Building Systems Involved:}

Building Infrastructure (structural systems)

Issue Statement:

In oractice, structural members are designed to withstand the forces induced by seismic excitations prescribed by building codes. The philosophy behind each building code is different, therefore, the reliability of structural safety is also different for structures subjected to severe earthquake motions. It is important that more rational design provisions be selected for "hi-tech" building projects.

Possible Applications:

Selection of either of the following documents as the basis for seismic design (they are more up-to-Gate provisions):

1. ATC 3-06, "Tentative Provisions for the Development of Seismic Regulations for Builäings," NBS SP 510, 1978

2. NESIR 81-2195, "Draft Seismic Standard for Eecieral Buildings," NBS Report, 1981 .

Other System Integration Requirements:

1. The seismic quaification (and design) of mechanical/electrical systems, utility supply syztems, piping anci equipment should also be basea on the structural response data obtained with the present design philosophy.

Constraints to Application: None.

Actions Necessary for Application Feasibility: Experienced engineering design firms have to oe seiected to perform seismic analyses and designs basad on Eelectec design provisions.

Points of Contact and/or Resources:

E. V. Leyendecker, 301-921-3471, CBT/lüBS

S. T. WU, 301-921-2I98, CBT/NBS 


\section{FPS- 6}

\section{FUNCTIONAL PROGRAMMING FOR EIGA TECENOLOGY PEDERAL OPFICE BOILDINGS}

\section{PUNCTIONAL PROGRAMMING STATEMENTS}

PROGRAMMING ISSOE:

Building Diagnostics -- Structural Performance

\section{Building Systems Involved:}

Building Infrastructure (Floor Systems)

\section{Issue statement:}

Eloor vibrations due to long unsupportea spans, high wind or machiries/eguipment may cause not only discomfort to occupants but also damage to structural members. Measurements of floor response will provide information for any required corrective action and development of design criteria.

Possible Applications:

To monitor floor response in terms of accelerations over $a$ frequency range of $0-50 \mathrm{~Hz}$ and identify when corrective action is warranted.

Other System Integration Requirements:

1. These devices may be included as part of the integrated system (if selected) for the building management, e.c., for fire safety, security, and thermal control.

Constraints to Application:

1. Cost may be the only constraint to inclucing this instrumentation.

Actions Necessary for Application Feasibility:

1. Select instrumentation based on measurement capabilities, limitations, reliabilities, costs, and installation deiails.

2. Calibrations may have to be performed periocicaliখ.

3. The iocations of the measurements must be prope:?! determined.

4. Measurements of the preoccupancy conditions of the building will be needed.

Points of Contact and/or Resources:

S. T. Wu, 301-921-2198, CBT/NBS

E. V. Leyendecker, 301-921-3471, CBT/LES 
FPS 7

FONCTIONAL PROGRAMMING POR BIGB TECENOLOGY PEDERAL ORPICE BOILDINGS

\section{PONCTIONAL PROGRAMMING STATEMENTS}

\section{PROGRAMMING ISSOE:}

Building Diagnostics -- Wind and Live Loads

Building Systems Involved:

Building Infrastructure

Subsystem)

(Superstructures Including Roof

Issue Statement:

To characterize the structural systems based on the floor accelerations as stated on FPS-6, the collection of wind and live load data will be useful. (Problems such as human sensitivity can also be evaluated based on these measurements.)

Possible Applications:

Installation of devices such as anemometers, strain gages, and interfacing recording systems.

Other System Integration Requirements:

1. These devices may be included as part of the integrated system (if selected) for the building management, e.g., for fire safety, security, and thermal control.

Constraints to Application:

1. Cost may be the only constraint to including this instrumentation.

Actions Necessary for Application Feasibility:

1. Select instrumentation based on measurement capabilities, limitations, reliabilities, costs and installation details.

2. Calibrations may have to be performed periodically.

3. The locations of the measurements must be properly determined.

Points of Contact and/or Resources:

R. D. Marshall, 301-921-2170, CBT/NES

B. R, Ellingwood, 301-921-3471, CBT/NBS 


\section{FONCTIONAL PROGRAMMING FOR EIGB TECANOLOGY PEDERAL OFFICE BOILDINGS}

\section{FUNCTIONAL PROGRAMMING STATEMENTS}

PROGRAMMING ISSOE:

Glazing and Antireflective Coatings

Building Systems Involved:

Builäing Enclosure (Windows)

Issue statement:

Space heating through use of southern exposure windows can be an effective energy conservation mechanism. To incresse effectiveness, it is desirable to use antireflective coatings or films on the interior of such windows to reduce heat losses.

Possible Applications:

Southern exposure windows.

Other System Integration Requirements:

Summer shading mechanism.

Constraints to Application:

None. Glass products with antireflective materials are commercialiv availabie. Even though test methods and standarcs are not available, manufacturers have limited performance and durability data that would be helpful in assuring quality.

Actions Necessary for Application Feasibility:

1. None for glass products (unless testing standards are necessary).

2. For organic (plastic) glazing, research is needed to Ensure longevity.

Points of Contact and/or Resources:

L. Masters, 301-921-3458, CBT/NBS

Ciark, E.J., Roberts, w.E., Grimes, J. ̈.., anc Emoree, E.J., Solar Energy Systems - Standards for Cover Plates for Flat Plate Solar Collectors, Nat. Bur. Stand. (U.S.), Tech. Noze 1132, Decenzer 1980 .

Clark, E.J. and Roberts, W.E., Weathering Performance of Cover

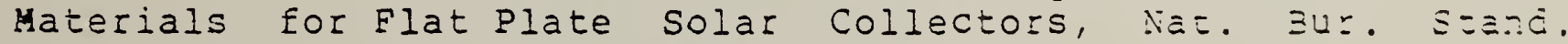
(U.S.) Tech. Note 1170, November 1982.

Energy-Effective Hindows, Nat. Bur, Szand, 512, Agril 1978 . 
Frohnsdorff, G., Masters, L.W., and Martin, J.W., An Approach to Improved Durability Tests for Building Materials and Components, Nat. Bur. Stand. (U.S.) Tech. Note 1120, July 1980.

Hastings, S.R. and Crenshaw, R.W., Window Design Strategies to Conserve Energy, Nat. Bur. Stand. (U.S.) Bldg. Sci. Ser. 104, June 1977.

Waksman, D., Streed, E., and Seiler, J., NBS Solar Collector Durability/Reliability Test Program Plan, Nat. Bur. Stand. (U.S.) Tech. Note 1136, January 1981.

Yancey, C.W.C., Materials Research Activities at the National Bureau of Standards (1975-1982) Pertaining to Active Solar Beating and Cooling Systems, NBSIR 83-2782, November 1983. 
FONCTIONAL PROGRAMMING POR BIGE TECENOLOGY PEDERAL OFFICE BOILDILNGS

\section{FONCTINAL PROGRAMMING STATEMENTS}

\section{PROGRAMMING ISSOE: \\ Security Glazing for windows \\ Building Systems Involved: \\ Building Enclosure (Windows)}

Issue Statement:

Windows are usually the easiest element in a building security system to breach. High security glazing materials have been developed to provide increased resistance to penetration. These glazing materials consist of laminated layers of giass and plastic films.

Possible Applications:

High security glazing materials are appropriately used when a high level of building security is desired and the wirdows are vulnerable targets.

Other Syster Integration Requirements:

None.

Constraints to Application:

1. Criteria have not been established for seiecting ingh security glazing materials.

2. Special window framing is required.

Actions Necessary for Application Feasibility:

1. NBS is developing performance criteria to aid in the selection of high security glazing. These criceria wili addres combined thermal and mechanical attack.

2. Additional work may need to be carried out on notoh crack sensitivity (i.e., effect of scratches on resiszance =o inpacz).

Points of Contact and/or Resources:

James R. Clifton, 301-921-3458, CBT/NBS 


\section{FUNCTIONAL PROGRAMMING FOR EIGB TECBNOLOGY FEDERAL OPFICE BOILDINGS}

\section{FONCTIONAL PROGRAMMING STATEMENTS}

\section{PROGRAMMING ISSUE:}

Single-ply Membranes

\section{Building Systems Involved:}

Building Enclosure (Roof)

Issue Statement:

Premature failures of built-up roofing membranes occur more Erequentiy than any other major builaing material, resulting in moisture penetration into buildings and loss of thernal efficiency. Single-ply membranes appear to be more durabie tran built-up membranes and more cost effective. It has been predicted that within the next 10 years single-ply materials will largely replace built-up roofing membranes.

Possible Applications:

Single-ply membranes are intended for use on low-sloped roofs. Undoubtediy they can be used wherever built-up roofing membranes are in service.

Other System Integration Requirements:

- Same as required for built-up roofing membranes.

Constraints to Application:

1. There is a lack of consensus standards ro form the bases for selecting single-ply membranes.

2. Methods need to be developed to determine the quality of seams constructed in the rield.

Actions Necessary for Application Feasibility:

1. Make contact with manufacturers/distributors of singie-ply roofing materials to establish features, performance, durability, cost, warrantee and installation details.

2. Make contact with ASTM D8 subcommittee dealing with singleply membranes.

3. Many available single-ply membrane materials are listed in the RST (Roofing/Siding/Institute) lg33 Handoook of Single-ply Roofing Systems. 
Points of Contact and/or Resources:

James R. Clifton, 30l-921-3458, CBT/NBS

walter J. Rossiter, 301-921-3109, CBT/NBS (information on ASTM Committee $\mathrm{D}-8$ )

National Roofing Contractors Association

Cullen, W.C., Rossiter, W.J., Mathey, R.G., and Clifton, J.R., Low Sloped Roofing Research Plan, Nat. Bur. Stand. (U.S.) Spec. Publ. 659, April 1983.

Rossiter, W.J. and Mathey,R.G., "A Methodology for Developing Tests to Aid Service-Life Prediction of Single-?ly Roo Membranes." Paper presented at the NBS/NRCA 7 th Conference on Roofing Technology, Gaithersburg, MD, April 14-15, 1983.

Rossiter, W.J. and Mathey,R.G., Elastomeric Roofing: A Survey, Nat. Bur. Stand. (U.S.) Tech. Note 972, July 1978. 


\section{FUNCTIONAL PROGRAMMING STATEMENTS}

\section{PROGRAMMING ISSOE:}

Diagnostic Monitoring of Mechanical Equipment

\section{Building Systems Involved:}

Building systems (BVAC)

\section{Issue Statement:}

Routine inspection of mechanical systems is a costly process. Likewise an unexpected failure in a mechanical component can result in expensive emergency repairs and/or temporary loss of building use with the attendant reduced user's productivity. A rationai approach to both maintenance scheduling and detection of potential equipment failure is diagnostic monitoring of the signal emitted by mechanical equipment.

\section{Possible Applications:}

Energy managenent, building security, fire and smoke management and communication systems.

Other System Integration Reguirements:

Communication, HVAC, security, fire anò smoke management.

Constraints to Application:

1. Complexity may delay start up.

2. Debugging may be required prior to achieving efficient operation.

3. Instailation costs may be high.

Actions Necessary for Application Feasibility:

1. Survey the availability of diagnostic monitoring systers to determine their application, operating characteristics anci cost as related to routine nechanical ecuipment operation.

2. The long-term servicing requirements and curability must aiso be established.

Points of Contact and/or Resources:

Simone L. Yaniv, 301-921-3783, CET/NES 


\section{FPS- 12}

PUNCTIONAL PROGRAMMING FOR BIGH TECBNOLOGY FEDERAL OPFICE BOILDINGS

FONCTIONAL PROGRAMMING STATEMENTS

\section{PROGRAMMING ISSUE:}

Lighting Controls, On-off Regulation; Task/Ambient Lighting

\section{Building Systems Involved:}

Building Systems (Lighting)

\section{Issue statement:}

While most lighting systems in builaings are manualiy controlled, many new buildings are being designed with computer-operated controls. An intermediate approach is suggested here -- one that would be based upon centralized computer control of ambient lighting, with individually controlled task lighting, tunable by means of a dimmer. This latter system would enable the operator to adjust lighting conditions for performance of different tasks, e.g., video display terminal or paper-based.

Possible Applications:

This system would be appropriate for all office-based activities.

Other System Integration Requirements:

The ambient system requires integration with other management systems of the building.

Constraints to Application:

Possible user resistance to automated controls.

Actions Necessary for Application Peasibility:

None, off-the-shelf equipment is available.

Points of Contact and/or Resources:

Arthur I. Rubin, 301-921-2246, C3T/NSS 
PONCTIONAL PROGRAMMING POR BIGB TECBNOLOGY PEDERAL OPPICE BOIIDINGS

\section{PUNCTIONAL PROGRAMMING STATEMENTS}

\section{PROGRAMMING ISSOE:}

building Management System - Integrated HVAC, Security, and Fire system

\section{Building Systems Involved:}

Building Systems (Energy Management and Control System (EMCS), Building Security, Fire Protection and Building Automation)

\section{Issue Statement:}

The increasing size and compiexity of buildings and the diversified capabilities of building management systems justify their installation. Although building management systems installed during the past had unsatisfactory results in reliability and start-up, the newer systems with better system architecture and improved components and software can make the system quite useful in plant operation, building energy reduction, space condition control, fire and security management.

\section{Possible Applications:}

The integration of energy management, HVAC system operations, HVAC system maintenance, data acquisition and management, fire and snioke management, security management, anò systeni alarms.

Systems should have state-of-the-art sensors, distributed EMCS (with stand-alone field interface devices), direct digital controls, and conventional/adaptive algorithms for IVAC system controls.

Other System Integration Requirements:

1. The building management system should be a system integrating EMC, fire, and security.

2. The fan operation of the air handing systems, duct smoke dampers, outside air, and exhaust air dampers must be integrated with fire and smoke controls.

3. The architecture of the system should be similar to that shown on the following diagram. With this architecture the EMC does not interfere with the occupancy of the builoing at the building startup or during down time. The Eire system overrides the other two systems when necessary.

4. AlI three functions (EMC, Eire, and security) should be stand-alone and have their own processors with individual functioned multiplexers connected to them. These satelite procsssors are integrated by a central processor which provides global control and data management. 
5. The building management system must be secured from interference so that the fire and smoke controls remain functional at all times.

Constraints to Application:

1. Due to the complexity of the building management syster, especially in the EMC part, delayed start-up, long time citugging, and malfunctioning during operation of the system may occur.

Action Necessary for Application Peasibility:

specifications of the system must meet the following: subsystens must be compatible, the fire part of the system must meet apgicable Iire codes ancilor national standards, and the system architecture be as cescribed below. It is of the utmost importance that the building design A/E be thoroughiy Eaniliar with the latest developments in building management systers.

Points of Contact and/or Resources:

Building management systems are available from ail large building control manufacturers and others.

James Kao, 301-921-3844, CBT/NBS

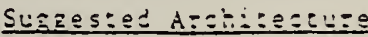

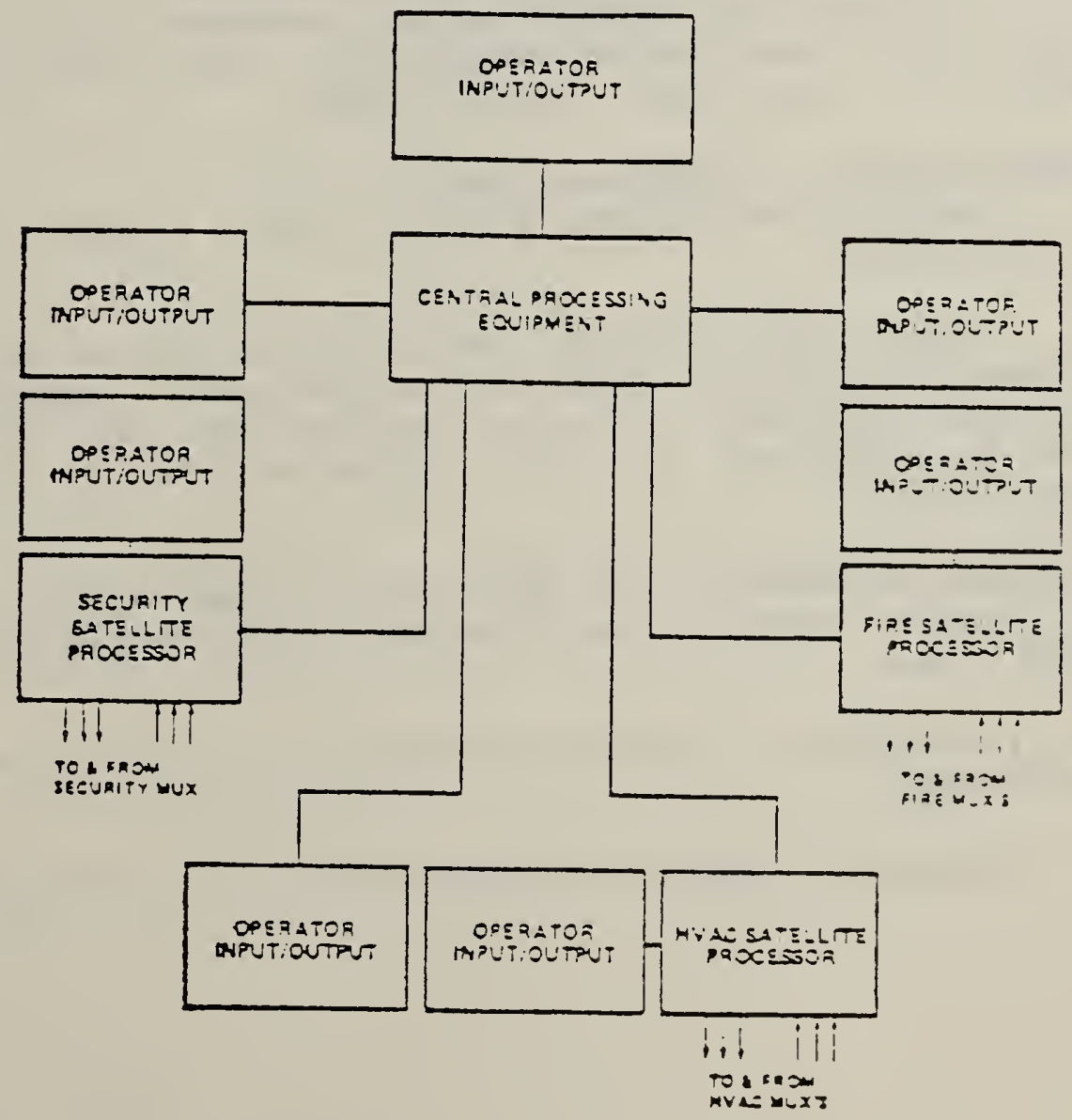


FPS-14

PONCTIONAL PROGRAMMING POR EIGE TECENOLOGY PEDERAL OFPICE BOIIDINGS

\section{PONCTIONAL PROGRAMMING STATEMENTS}

\section{PROGRAMMING ISSOE:}

Advanced BVAC Systems and Control strategies

Building Systems Involved:

Building systems (HVAC)

\section{Issue Statement:}

Numerous GVAC subsystems and control strategies which have been proven to be energy efficient in private and public sectors applications have the potential to be used in proposed GSA buildings. These subsystems include heat recovery, heat pump systems, solar applications and thermal storage applications. The main deciding factor in their application to a building is economy and, to a lesser degree, the complexity of their operation. Variable air volume systems should be used whenever possible.

Possible Applications:

All the subsystems listed above have the potential for application.

Other System Integration Requirements:

1. No specific requirements, however, like other HVAC systems, they may need to be compatible with building architectural, structural and electrical systems.

Constraints to Application:

1. Cost of installing some of these systems may be a constraining factor.

2. Since the energy saving benefit can only be realized if these systems are operated as designed, and since the operation of these systems are more complex than for conventional systems, the availability of operating personnel may also be a constraining factor.

Actions Hecessary for Application Peasibility:

1. Life cycle cost analysis should be performed in deciding their use.

2. Thorough training program should be given to the operating personnel.

3. Complete operating manual should be available. 
4. An A/E firm with strong experience in HVAC system and control design should be selected.

Points of Contact and/or Resources:

$\mathrm{J}$. Kao, 301-921-3844, CBT/NBS 
PONCTIONAL PROGRAMMING POR BIGE TECBNOLOGY PEDERAL OPPICE BOILDINGS

\section{PONCTIONAL PROGRAMMING STATEMENTS}

PROGRAMMING ISSUE:

High Efficiency HVAC Equipment

\section{Building Systems Involved:}

Building systems (HVAC)

Issue statement:

With varying loads, the most efficient way for turbo-machinery to match the load and capacity is to vary the speed. The recent advancement in motor speed controls make speed control of some turbo-machinery used in HVAC systems more practical.

Possible Applications:

Air handing fans (as used for VAV systems), large chilled water pumps, and centrifugal refrigeration machines are possible candidates.

Other System Integration Requirements:

None, except with electrical systems in an ordinary design sense.

Constraints to Application:

1. The cost of variable speed motor controller may still be a factor preventing their use.

2. With variable speed motors the associated flow systems are inherently complex. Therefore, the design and operation of these systems are more complex.

Actions Necessary for Application Peasibility:

1. An engineering feasibility study, including a life cycle analysis, should be performed to analyze the economy and system stability.

2. Because of the increased complexity of the variable flow systems, designers with experience in variable speed equipment and systems should be chosen.

Points of Contact and/or Resources: James Rao, 301-921-3844, CBT/NBS 


\section{FPS -16}

\section{FONCTIONAL PROGRAMMING POR BIGE TECENOLOGY FEDERAL OFPICE BOILDINGS}

\section{PUNCTIONAL PROGRAMMING STATEMENTS}

\section{PROGRAMMING ISSUE:}

Building Operation Local Area Network

\section{Building Systems Involved:}

Building systems (Communications)

\section{Issue statement:}

In order to reduce redundancy and to establish compatibility between various building management and control systems (energy, fire safety, security, etc.), there is a neeò to share data produced by various building sensing and communicating devices and to simplify the associated communication wiring. One means for meeting the need for compatibility between managenent and control systems is through the use of a local area network (LAr) that supports both video and data transmission.

\section{Possible Applications:}

Consideration should be given to using a dual cable LAN connecting all sensing and communication devices used for building management and control. Possible LAN topologies to use are bus and partialiy connected mesh. Carrier sense llultiple Access with Collision Detection (CSMA/CD) is the proposed communication protocol. Broadband coaxial cable employing Ereguency-civision multiplexing is the proposed transmission medilim.

Other system Integration Requirements:

1. The design of the LAN cabling system should prevent voitage hazards by contact between communication circuit elenents anc electrical system elements.

2. The LAN installation should minimize the chance for the occurrence and spread of fire and the generation and spread oj smoke within a building.

3. Consideration should be given to cabie insulation if it is located in spaces used for the transport o enrironnenta: a i. .

4. Adequate space to safely service LAN equiprent a:d dabing shouid be provided throughout a building.

5. LAN cable and equipment weight should ze considezó determining structural requirements where apolicable.

6. Protection against the affects of nigr elec:romagre:icradiated fields should be considered in the cesic: a.d installation of the LAN. 
7. LAN components are designed to operate within specified gaseous and particulate environmental limits.

Constraints to Application:

1. Although the IEEE 802 committee is working on standards for the data link and physical layers or network nodes, standards do not exist for the higher levels. As a result, when an installation requires that various devices be supported, the requisite multiplicity of interfaces at higher levels may not be possible.

2. When physical security or other requirements necessitate redundancy of the various functions performed by the network, costs may be prohibitive.

3. The cost of multiplexing associated with a dual loop coaxial cable may be significantly more than a transmission medium design predominantly composed of twisted pair copper cable.

Actions Necessary for Application Reasibility:

1. Procurer must determine LAN requirements:
A. Required services
B. Network traffic characteristics
C. Reliability requirements
D. Network growth
E. Maintenance requirements

Points of Contact and/or Resources:

George E. Turner, 301-9-21-2140, CBT/NBS

Intelligent. Building Information Systems, 1225 Jefferson Davis Highway, Arlington, VA 22202, 703-486-5627

Nathan Steele, President, SES, Inc., 7310 Ritchie Highway, Glen Burnie, MD 21061, 301-787-0745

Rosenthal, Robert, ed., The Selection of Local Area Computer Networks, Nat. Bur. Stand. (U.S.) Spec. Publ. 500-96, November 1982 . 


\section{FPS -17 \\ FONCTIONAL PROGRAMMING FOR EIGB TECANOLOGY PEDERAL OPFICE BUILDINGS}

\section{FONCTIONAL PROGRAMMING STATEMENTS}

PROGRAMMING ISSOE:

Fire Safety

Building Systems Involved:

Building Systems (Fire Protection)

Issue Statement:

The object of this program statement is to develop an innovative fire safety approach that makes optimum use of the newest equipment and concepts while producing the maximum flexibility for other technologies and building uses.

The design and equipment concept presented herein proposes a major departure from current practices to provice safety with increased economy and the flexibility needed for a high tochnology application. The system described is an integrated arrangement presented as a packace. If the package is used in part, instead of in its entirety, special studies will be necessary to determine the impact on the safety objectives of GSA. The system presented here, however, has sufficient deprh of redundancy and safeguards that it is believed that the system will procirce levels of safety that meet or exceed normal GsA objectives.

Attached is a draft of a completed fire safety section of a CSA project directive sheet. It was used as a convenient method in summarizing the items. Some of the key concepts inciude:

a. Structural system. The proposed approaci elininates the fire resistance and smoke tightness requirements ior the structural deck, including the secondary bearing memers for that deck. The approach also reduces in fire resistance Ecr tie principal bearing members from the traditional tio nour Eire resistance to a fire resistance of approximately 45 minutes. This will permit the design of a floor and ceiling systen witich can be readily accessible from both top and bottori and can carry all of the building utilities and simultaneolsiv be used as either a suppiy or return air plenum. The elimination of Eire resistance will also eliminate the need Eo: Eithe: jsiestos o: asbestos substitute fireproofing material for the deck.

b. Sprinkler system. The concept invoires a $\because e: y$ spec: sprinkler arrangement that is critical to the incended zin safety. It is proposed that two separate sprinklez \$ysten: ce proyided, one covering the interstitial spaces betrieen the jioc: deck ard ceilings and the other covering the genezal area oj ine 
building. It is further proposed these systems be provided with the newly developed fast response off-on sprinkler systems. The systems are to be separately integrated with building utility water supply with no valves that may shut down the sprinkler system without simultaneously taking essential utilities out of service. A diagram of a possible arrangement is included on page 34. This is to assure that the sprinklers are treated as an essential building utility and any shutdown results in prompt emergency-type repairs as would be applied to a loss of power or domestic water. Further, it is intended that each sprinkler system be tied to separate utilities so that one may be taken down without taking down the other. Water flow alarm is to be provided on each floor of each system with devices that both detect and measure flow.

c. Smoke control. The concept envisions a smoke control system zoned so that the floor involved in fire operates in a negative pressure mode and the rest of the building operates as a positive pressure. This is felt important in view of the deletion of requirements for smoke tightness of the floor decks.

d. Emergency communications and controls. The fire safety system visualizes using all of the various environmental sensors that the high technology application will bring as a means of fire detection. It is intended that the system be arrarged to be "smart" so that the control center will have exact information on sources of detectors, levels of detectable quantities where analog arrangements are involved, and the amount and general location of any water flow taking place in sprinkler systems.

e. Eurniture. It is proposed that consideration be given to special furniture control. The building control center software would be provided with the most current fire growtin models and state-of-the-art capability to predict the potential impact of fire from rate of heat release data on the furniture involved. Such data would require some testing. The object being to maintain the furniture fire potentials low enough to prevent the possibility of flashover and to assure that the maximum fire be in the range of approximately 20 minutes in all spaces not designated and designed to handle special hazards.

\section{Possible Applications:}

The application of the type of system proposed covers the full scope of elements listed. The primary reasons for such application rest in the need to have flexible point-to-point access for wiring and utilities in a high technology building. Elexible accessibility can be provided from a full access floor and ceiling arrangement. In addition, the concept can provide maximum flexibility for a space utilization. There also is a possibie cost saving due to the elimination of the heary concrete slabs. The amount of the cost of the saving, however, depends upon the approaches taken in seismic protection. 
Other System Integration Requirements:

1. This approach needs to be integrated with structural, mechanical, electrical, space assignment, and building management
integration operation.

Constraints to Application:

1. This approach is considered to provide reasonaise anj effective fire safety. However, it is based on the professional analytical confirmation wouneers involved. Development of an anaiytical confirmation would involve a major reseacch effort.

Actions Necessary for Appliication Feasibility:

l. Since this approach involves a deviation fron the is proposed under the criteria and procedures in GSi hancioooks, it 2c OI GSA Handbook, Building Fire Safety found in Chazter ICEGE 18, October 24, 1980).

2. The approach is sufficientiy conservative so that the basic concept can be maintainea even if some of the elements are folnd to be infeasible or otherwise undesired. Sore elements are, however, critical to the concepts. Reevaluacion will be essential if any changes are desired.

3. Coordination with almost all other design areas (structural, mechanical, electrical, architectural) is necessary.

4. Rate of heat release testing of typical furniture iters wil be necessary to implement the proposed furniture control aspecis

Points of Contact and/or Resources:

Earola E. Nelson, 301-921-3175, CEP/NBS 
PROJECT DIRECTIVE - FIRESAFETY

PROJECT TITLE

Hign Tech Buildings

\begin{tabular}{r|l|l}
\hline NUMBER AND STREET & CITY \\
\hline SECTION & . STRUETURAL FEATURES \\
\hline
\end{tabular}

\begin{tabular}{|c|c|c|c|}
\hline \multicolumn{2}{|c|}{$\begin{array}{l}\text { STRUCTURAL } \\
\text { FIRE RESISTANCE }\end{array}$} & General & Hazardous Azeas \\
\hline \multirow{2}{*}{ WALLS } & OEARING & $\approx 45 \mathrm{~min}$. & Individual \\
\hline & NON BEARING & Na pea & enclosure \\
\hline \multicolumn{2}{|c|}{ COLUMNS } & & fire res. On \\
\hline \multirow{2}{*}{ 8EANS } & PRIMARY & $\approx 45 \mathrm{~min}$ & cese hy case \\
\hline & SECDAOARYY & Yo Rec. & basis) \\
\hline \multirow{2}{*}{ orexs } & FLOOR & No Rer * & \\
\hline & ROOF & No Rec. & \\
\hline \multicolumn{3}{|c|}{ *Floor deck and ceiling } & \\
\hline & are tora & & \\
\hline
\end{tabular}

FIRE WALLS

are toral access.

None unless needed for exposure protecrion

FIRE PARTITIONS

Smoke tight on each floor (no fire resistance)

VERTICAL OPENINGS AND SHAFTS

Smoke tight (no fire resistance)

PANEL. CURTAIN. ANO SFANOREL WALLS

Smoke stopped at floor deck

CEILINGS Free access-Void (interstitual) elec, plumbing, and othe usilities.

FIRE STOPS

Also return air

FIRE DOORS

Smoke stops as necessary for cholo control cystom

Auto. closing (bv detection sustem)

STAIREELL DOORS

Auto closing with hold opens (easv access doces)

DOOR

HARD.

WARE

QILING ExITS

SMOKE CONTROL DOORS

Auto closing

OTAER - SFECIAL

UTILITIES/STRUCTURAL INTERFALE

Use incersticual, cable allowed in interstizual

ATTACHMENTS ANO ADOITIONS

EXPOSURE PROTECTION

As needed

\begin{tabular}{|c|c|c|c|c|c|}
\hline \multicolumn{6}{|c|}{ SECTION II. OCSUPANEY LIMITATIONS } \\
\hline 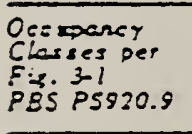 & special fur & niture control & based on enezo & $100 d$ & \\
\hline GROUF I & (Necessarv & Eamouter madel & $I_{i}=i \cdots+i=i-0$ & & \\
\hline GROUP I & constei & sompurerl & 1 & & \\
\hline GROUP II & & & 1 & & \\
\hline GRQup I & & 1 & I & & \\
\hline & & & $I$ & & \\
\hline & & & I. & & \\
\hline
\end{tabular}




\section{PROJECT DHRECTIVE. FIRESAFETY (Continued)}

PROJEET TITLE.

NUMEE AMU STPEET

CITY

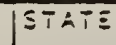

\section{SECTION III - INTERIOR CONSTRUETION ANO ARRANGEMENT REQUIREMENTS}

INTERIOR FIMISH

Ceilings $=$ Class $A$; Walls $=$ Class $A, B$, or $C^{*}$

Carpering $=$ No special requirements

*Combustibles added to energy load.

PARTITIONS

No special requirements*

*Anv combustibles ażed to enezz": load

EXIT IOR OTHER EMERGENCY MOVEMENTI FACILITIES ANO ARRANGEHENTS

Two stalrs, sized on dynanic flow calculations. Siairs desizned es atosss引j: inviting and normally open. Sooke enclosure at ti=e ó̈ íize.

\begin{tabular}{|c|c|c|c|c|}
\hline & FLOOR (S)/SPACE & $\begin{array}{c}A R E A \\
\left(5 q . F_{6 .}\right)\end{array}$ & $\begin{array}{l}\text { EXFEETED } \\
\text { POVLLTIOH }\end{array}$ & 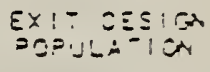 \\
\hline \multicolumn{5}{|l|}{ BUILO. } \\
\hline \multicolumn{5}{|l|}{ ING } \\
\hline \multicolumn{5}{|l|}{ POPU. } \\
\hline \multicolumn{5}{|l|}{ LATION } \\
\hline & & & & \\
\hline & & & & \\
\hline & & & & \\
\hline & & & & \\
\hline
\end{tabular}

SEGREGATION CF HAZARES

Yes

PLACES OF CONFINEMENT

None Involvej

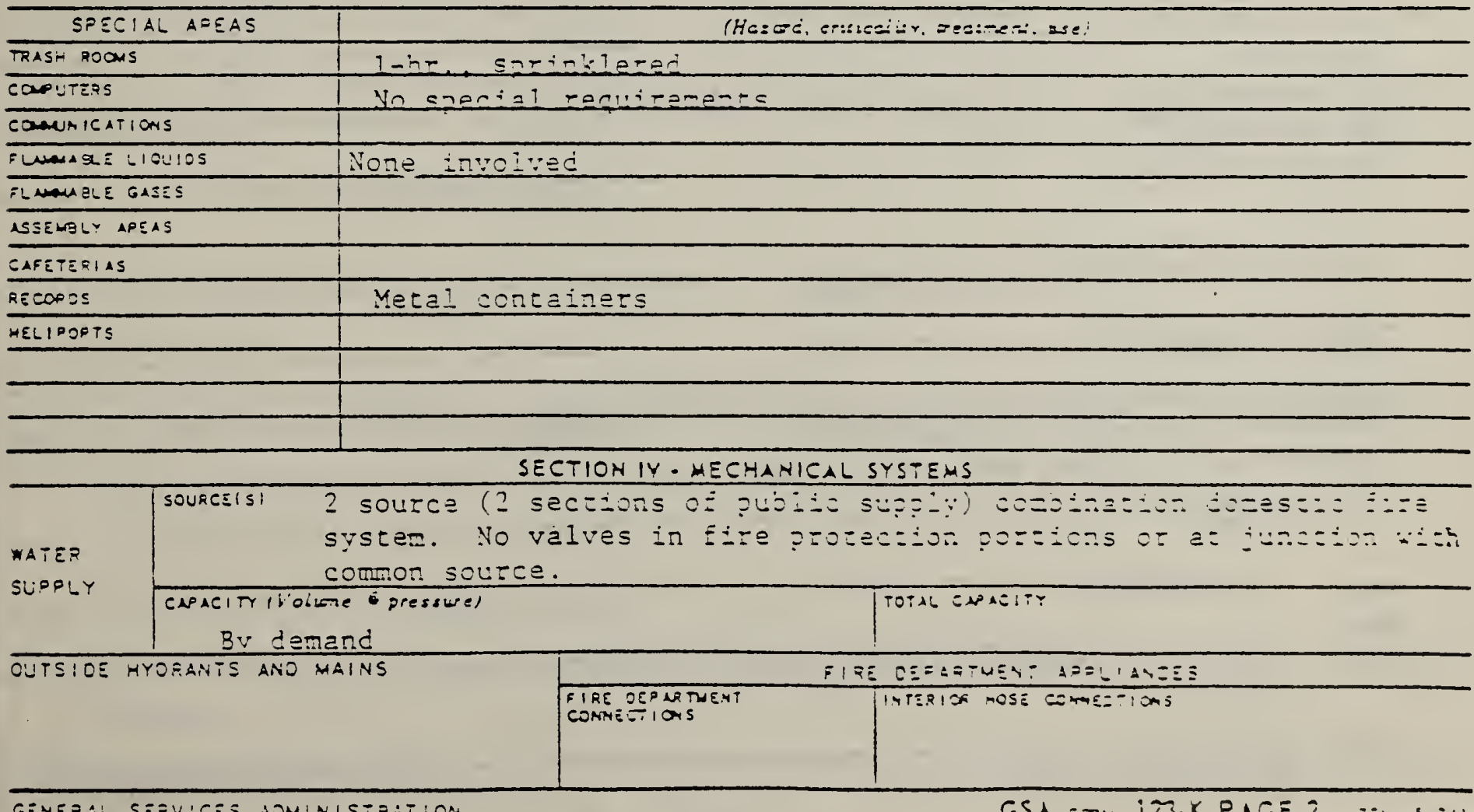


PROJECT DIRECTIYE - FIRESAFETY (Continund)

PROJECT TITLE

\section{NUMBER AND STREET}

\section{SECTION IV - MECHANICAL SYSTEMS (CONHINUCd)}

AUTO.

AUTO. SPACES TO BE PROTECTED

Entire building including in: - Eirual soaces.

MATIC

SPRIN.

$K L E R$

PROTEC.

TION

Two separate systems from tri.

\section{irces (see diagram)}

Fast resoonse, off/on heads - scaggered

Plastic oide acceotable

Suodiv is valveless

ivarer flow bu floor, rate derfcred

\section{FIRE PROTECTION WATER DISTRIBUTION SYSTEM}

Combined with domestic

SPECIAL EXTINGUISHING SYSTEMS

AIR CONDITIONING

No fire dampers

SMOKE CONTROL SYSTEMS

Zoned by floor (exinaust fire floor, supoly only to rest of bldg.) HEATING SYSTEMS

GAS PIEING ANO APPLIANCES

INTERNAL COMEUSTION ENGINES

\begin{tabular}{|c|c|c|}
\hline \multicolumn{3}{|c|}{ SECTION Y. ELECTRICAL SYSTEMS AND EQUIPHENT } \\
\hline & QANSFORMERS & LOEATIONISI \\
\hline \multicolumn{3}{|c|}{ PUBLIC UTILITY SUPPLIED } \\
\hline \multicolumn{3}{|c|}{ IN CONTRACT } \\
\hline \multicolumn{2}{|c|}{$\begin{array}{l}\text { OUTSICE SUESTATIONS } \\
\text { ANO TRANSFORMERS }\end{array}$} & PRTtECTIOA \\
\hline \multicolumn{2}{|c|}{ OISTRISUTION SYSTEMS } & UNOERFLOOR SYSTEM.SI \\
\hline \multicolumn{3}{|c|}{ WIRE CLOSETS (AND OTHER VERTICAL PASSAGES) } \\
\hline \multicolumn{3}{|c|}{ LIGHTNING PROTECTION } \\
\hline \multicolumn{2}{|c|}{$\begin{array}{l}\text { ExIT LIGTS Special, respords to fire } \\
\text { information to flasi and indicate safe path }\end{array}$} & $\begin{array}{l}\text { EMERGENCY LIGHTING } \\
\text { Eigh and low elevation lights }\end{array}$ \\
\hline \multirow{3}{*}{$\begin{array}{l}\text { EMER. } \\
\text { GENCY } \\
\text { POWER }\end{array}$} & SOURCE & $\operatorname{csp} x \cos$ \\
\hline & STARTIMG METHOO & TILE TO ON-LINE \\
\hline & \multicolumn{2}{|l|}{ CIRCUITS NO EOUIPUENT ON DEREENCT STSTE } \\
\hline \multicolumn{3}{|c|}{ GENERAL SERVICES ADMINISTRATION } \\
\hline
\end{tabular}


Elevarors - Lobby smoke barrier, load cell to rell if evacuees are waiting.

PROJECT DHRECTIYE . FIRESAFETY (Continued)

PROJEET TITLE

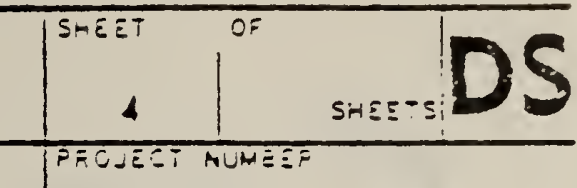

NUNEER ANC STREET

CITY

STATE

\section{SECTION VI. EMERGENCY COMHUNICATIONS AND CONTROLS}

EXPLAIN

\begin{tabular}{|c|c|c|c|c|}
\hline \multirow[b]{2}{*}{ INPUT } & \multicolumn{4}{|c|}{ nals, Seattle tvoe oul? boxes } \\
\hline & \multicolumn{4}{|c|}{$\begin{array}{l}\text { Automitl Building environmental controls, Smart saoke dezectors, springer } \\
\text { water Elow. }\end{array}$} \\
\hline \multirow{6}{*}{ OUTPUT } & \multirow{4}{*}{$\begin{array}{l}\text { AUTO. } \\
\text { MATIC }\end{array}$} & $\begin{array}{l}\text { ALARMS IN } \\
\text { SUILDING }\end{array}$ & Voice & $\begin{array}{l}\text { covalge } \\
\text { Total }\end{array}$ \\
\hline & & \multicolumn{3}{|c|}{ EOUIPMENT CONTKOLS } \\
\hline & & $\begin{array}{l}\text { SIGMALS } \\
\text { OUT OF } \\
\text { BUILOIMG }\end{array}$ & $\begin{array}{l}\text { FIRE DEPARTEMT } \\
\text { YeS }\end{array}$ & $\begin{array}{l}\text { PTHER (Spectiy) } \\
\text { GSA Centers }\end{array}$ \\
\hline & & \multicolumn{3}{|c|}{ OTHEF (SpESIfY) } \\
\hline & \multirow{2}{*}{ MANUAL } & \multicolumn{2}{|c|}{ ALARIS ANO SIGNALS } & $\begin{array}{c}\text { EOUIRENT COMTROLS } \\
\text { YES }\end{array}$ \\
\hline & & \multicolumn{3}{|c|}{ OTHER (Specify) } \\
\hline \multirow{3}{*}{ STATUS } & MAUACIATI & \multicolumn{2}{|c|}{$\begin{array}{c}\text { CTR in Control Center and } \\
\text { on ioors }\end{array}$} & PRIATERS/REEOCEAES \\
\hline & \multicolumn{3}{|c|}{ TROUBLE INOICATIONS } & $\begin{array}{l}\text { REAL TIME SYSTEYS OATA } \\
\text { YES }\end{array}$ \\
\hline & \multicolumn{4}{|c|}{$\begin{array}{r}\text { OiMER (Spetíly) } \\
\text { Real time Eire involvemene dasojire }\end{array}$} \\
\hline
\end{tabular}

RELIAEILITY FEATURES

SECTION VII - EMEREENCY PIAN

Ex+L14

SECTION VIII - COORDINATION WITH NONFIRESAFETY SYSTENS

EXPLAIN

|ACCIOENT ANO FIRE RPEVENTION OIYISIOA

APPROYED

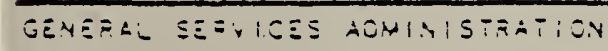

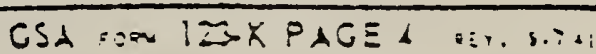




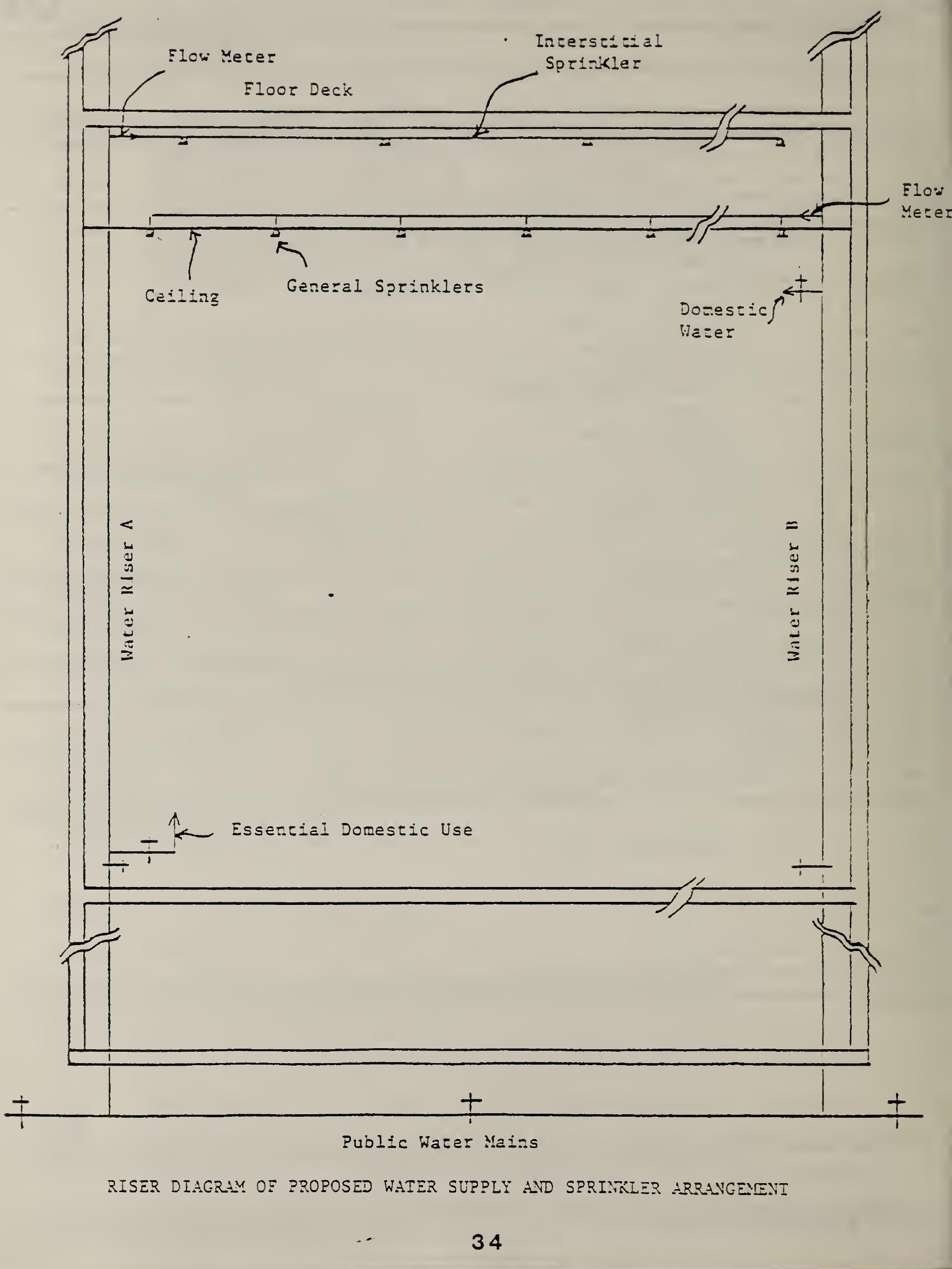




\subsection{RESEARCE NEEDS STATEMENTS}

\subsection{Introduction}

The statement sheets contained herein are organized, to the extent possible, according to the categories of GSA design directives. The complete list of design directive categories can be found on page 3 .

\subsection{Statements}

The statements are presented on the following 26 pages sith a ach statement formatted separately in a standardized layout. 


\section{RNS-1}

\section{RESEARCE PLANNING POR BIGE TECBNOLOGY FEDERAL OPFICE BOILDINGS}

\section{RESEARCE NEEDS STATEMENT}

\section{RESEARCE ISSOE:}

Evaluation of the Long-Term Performance of the Base Isolation system (BIS)

Building Systems Involved:

Structures implemented with BIS

Problem Statement:

The short-term performance of BIS has been simulated with numerical analysis as well as with shake table tests. It is known that the lateral design forces in the structural system can be greatly reduced (see attachment). Nevertheless, the long-term performance of BIS through the life span of the structure has to be evaluated and predicted to ensure structural safety in the event of strong earthquake excitations.

Technical Approach:

The approach will be:

1. identification of the qualified base isolation systems or devices

2. cevelopment of the methodology, including modeling (tests if needed)

3. preparation of the report(s).

Product:

Report(s) giving the results of the investigation.

Implementation:

Presentation of the results at conferences, in journal publications, and interaction with industry and research organizations.

Impact:

A rational basis will be developed for the evaluation of longterm performance of the BIS. The results will be useful to industry as well as to GSA in the planning and design of public office buildings located in high seismic index zones.

Milestones:

1. Identify the qualified base isolation systens/devices - 3 months. 
2. Develop the methodology and models for the evaluation - lIz months.

3. Complete the report with recommendations - is month. .

37 


\section{Attachment}

\section{Base Isolation System: Schemes and Effects}

The concept of "base isolation" is to decouple the building structure from strong earthquake ground motions by a special scheme. With the scheme, transmissions of horizontal accelerations into the structure can be greatly rejuced. A brief description of this modern device and its effects on the base isolated structure are given below.

\section{The Schemes}

There have been various schemes developed to fulfill the goal of isolating structures from strong ground motion. An effective scheme should have a damping mechanism and a device that provides rigidity under low load levels. One such scheme, recognized as a lead/rubber bearing system, is shown in Fig. I (Ref. I). This scheme has been developed and used in New zealand. There are various schemes being developed in other countries, e.g., Greece, Yugoslavia, South Africa, and France (Refs. 2-5). In this country, similar types of schemes have been developed and tested, see, Refs. 1 and 6 .

\section{The Effects on the Structural system}

A fail-safe base isolation system has been designed for a fivestory building at the university of California, Berkeley. The system was tested on a shaking table with different kinds of simulated earthquake motions. Frame accelerations for the EI Centro input signal with different isolation conditions are shown in Fig. 2. As can be.seen from the figure, the lateral design forces on the structures are reduced greatly. Details of this test can be found in Ref. 7 .

\section{References}

1. Relly, J.M., "Aseismic Base Isolation: Its History and Prospects," Joint sealing and Bearing systems for Concrete Structures, ACI Publication SP-70, Detroit, 1981.

2. Ikonomou, A.S., "The Earthquake Guarding system," Technica Chronica, Vol. 4l, 1972 .

3. Roth, A., et al., "Erbebenischerung im Bauen: Das Schulhaus 'Heinrich Pestalozzi' in Skopje, Jugoslavien," Neuen zurcher zeitung Beilage Technik, 1970 .

4. Plichon, C,, "Hooped Rubber Bearings and Ericticnal Plates: A Modern Antiseismic Engineering Technique," Proceedings, Special Meeting on the Antiseismic Design of Nuclear Installations, Paris, Erance, 1975 . 
5. Delfosse, G.C., "The GAPEC Systeri: A view Highly Effective s seismic system," Proceedings, The Sixth world Conference on Earthquake Engineering, New Delhi, India, 1977.

6. Engineering News-Record, "Law Builöing Can Roil with Bunch," August $\leqslant, 1983$.

7. Kelly, J.M. and Fodder, S.B., "Experimental Study of Lead and Elastoneric Dampers for Base Isolation Systems in laminated Neoprene Bearings," Bulletin of the New zealand National society for Earthquake Engineering, Vol. 15, No. 2, June, 1982.

39 


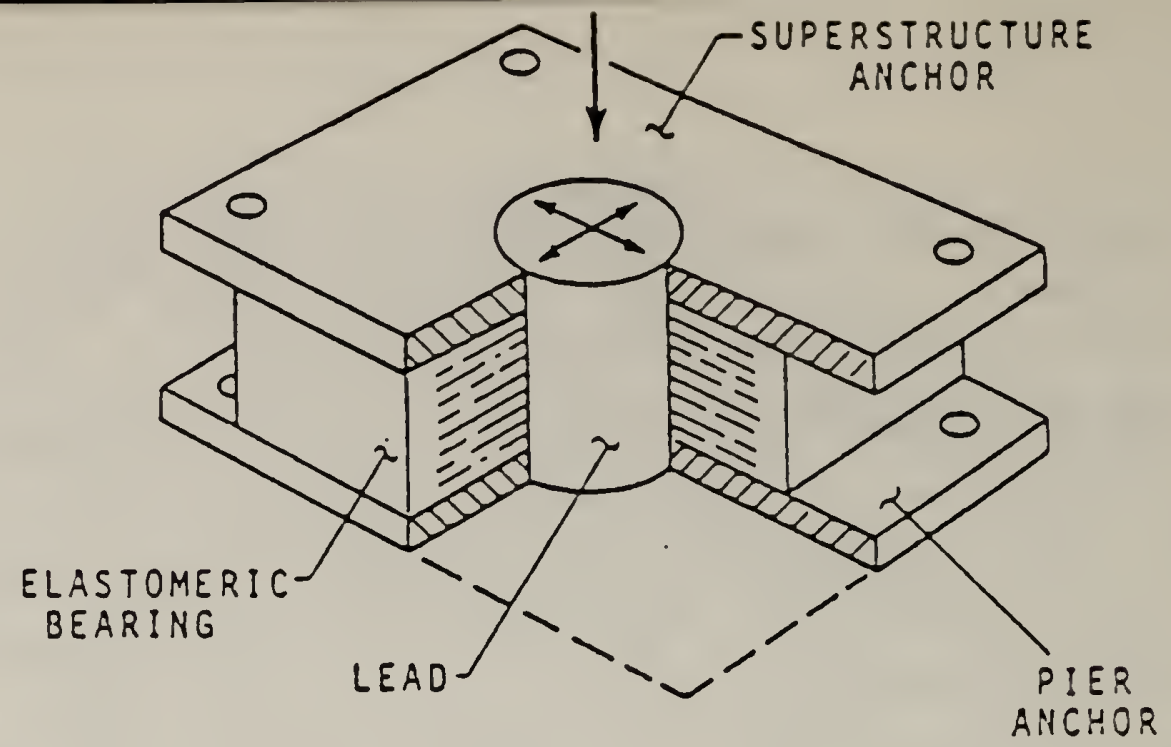

Figure 1. The lead/rubber bearing of the iew Zealand Systen(Re三. 1).

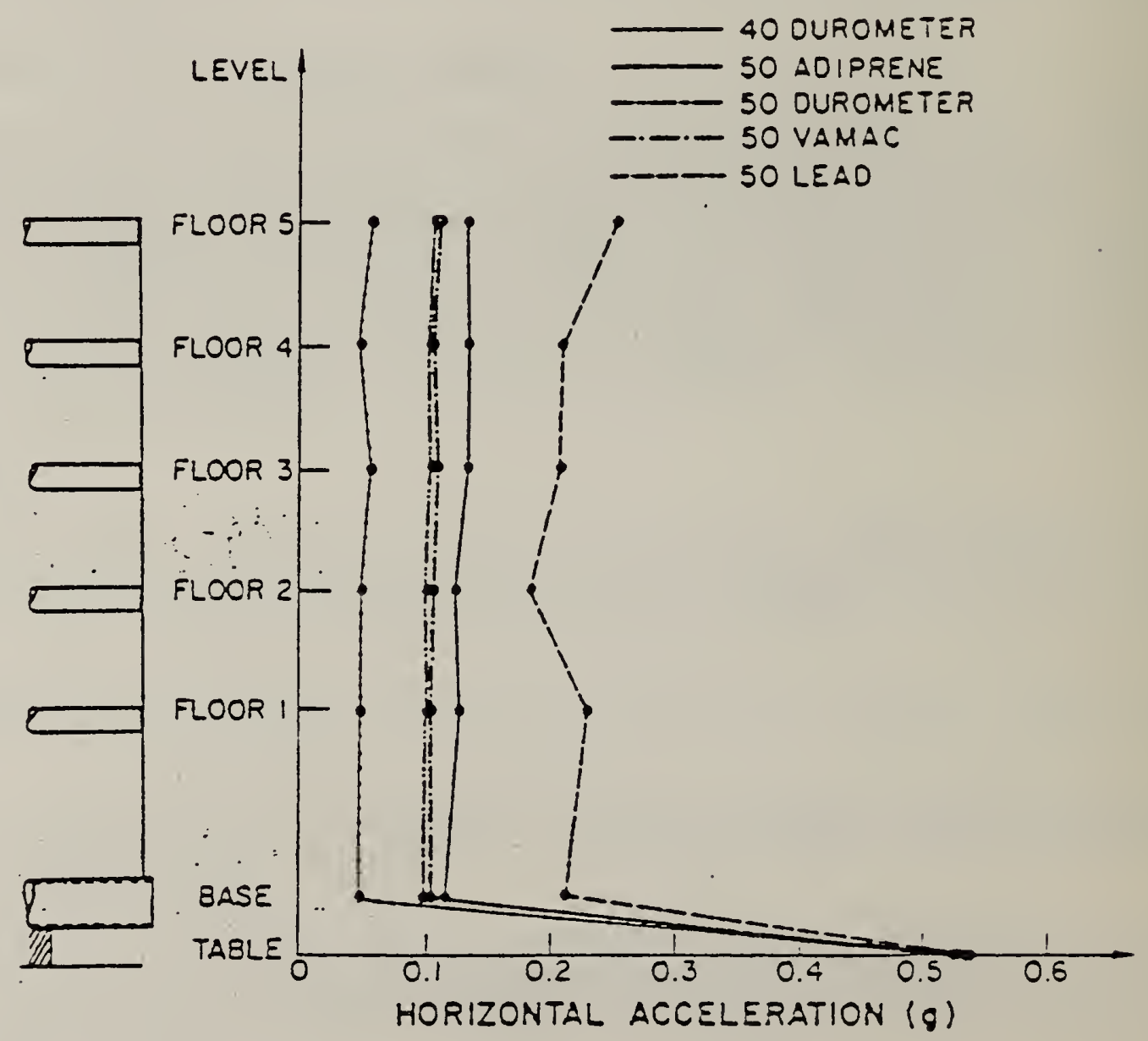

Figure 2. Frame accelerations for El Centro input sisnal with different isolation conditions(ReE. 7). 


\section{RNS-2 \\ RESEARCB PLANNING FOR EIGB TECBNOLOGY FEDERAL OPFICE BOILDINGS}

\section{RESEARCB NEEDS STATEMENT}

\section{RESEARCE ISSUE:}

Octimum Dynamic Parameters for Structures with Absorber systems

Building systems Involved:

Structures including superstructures and absorber systems

Problem Statement:

Structural optimization has been investigated extensively in the past two decades. Optimization of dynamic systems with absorbers has considered primarily single degree-of-freedom systems and emphasized selection of absorber stiffness and damping. irith recent developments in absorbers (e.g., the base isolation system) for mitigating strong earthquake-induced responses, structural optimization for multidegree-of-freedom systems should be studied. The basis for selecting the objective sunction should not be limited to only the weight of the building and more significant constraint conditions should be imposed (e.g., consideration should be given to the dispiacements of the mechanical and structural systems as well as to acceleration of the structural systen!).

Technical Approach:

1. Determine the significant parameters for the selected objective functions for various types of absorber systems.

2. Develop analytical models including the proper selEction of the constraint conditions.

3. Evaluate sample problems based on the approach deveicjec.

4. Provide guidance or criteria for the design grocsss.

Product:

Report(s) presenting the results of the study.

Implementation:

Dresentation of the resulis at conferences, in jouzna: publicaticns, etc. Results of this type of sudy nay be trelöl: for an economical design of the current Long seach, cj groject.

\section{Impact:}

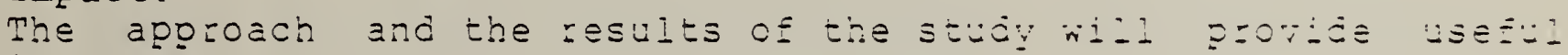
information to the builcing industry for the econorida: structures. 
Milestones:

1. Determine the significant parameters for the selected objective function - 3 months.

2. Develop the model including the selection of the proper constraint conoitions - 12 months.

3. Evaluate the structural systems (case studies) - 15 months.

4. Report with guidelines - 18 months. 


\section{RNS-3}

\section{RESEARCE PLANNING POR BIGH TECENOLOGY FEDERAL OFPICE BOILDINGS}

\section{RESEARCE NEEDS STATEMENT}

\section{RESEARCB ISSOE:}

Building diagnostics

\section{Building Systems Involved:}

Multiple

Problem Statement:

Problems of shortcomings in the performance of building materials are frequently not detected until considerable damage has cccurred. An example of this is a leaking roof. With recent advances in nondestructive evaluation technology, it may be feasible to incorporate NDE tools into builaings to provide diagnostic data.

Technical Approach:

1. Develop criteria for NDE and other tools which may aid in diagnosing problems or impending problems.

2. Provide the technical basis for use of builaing diagnostics through iaboratory and field data.

\section{Product:}

Research reports presenting the results of the studies ard including criteria for building diagnostics will be produced.

Implementation:

Through publications, presentations to the building community and interactions with stanords setting organizations.

\section{Impact:}

1. Reduce maintenance costs.

2. Improve builöing performance.

Milestones:

1. Analyze building diagnostic needs - 3 morths.

2. Identify promising diagnostic methods - S months.

3. Laboratory and field data collection - 12 months.

4. Report on criteria for selecting useful ciacnos íc -a 36 months. 


\section{RESEARCB PLANNING FOR HIGH TECANOLOGY PEDERAL OPFICE BOILDINGS}

\section{RESEARCE NEEDS STATEMENT}

\section{RESEARCB ISSUE:}

Expert systems for selecting coatings and paints based on consideration of protective requirements and weather conditions

\section{Building Systems Involved:}

Building Envelope

Problem Statement:

Often sufficient information is not readily available on materials performance and durability to make decisions on selecting durable coatings and paints materials. Expert systems can be potentially effective in making high quality decisions in the selection of durable materials. Expert systems are computer programs which mimic the reasoning of human experts.

\section{Technical Approach:}

The knowledge of experts on the performance and durability of coatings and paints will be recorded in the form of a knowledge base and heuristic rules. They will be encoded in a computer program which can give recommendations at or near the level of human experts thus facilitating and improving the selection process.

\section{Product:}

An expert system for selecting coatings and paints will be developed and its usefulness demonstrated.

Implementation:

The expert system will be implemented through its use in selecting coatings and paints.

\section{Impact:}

Development and use of the expert system will result in improved selection of coatings and paints, thereby reducing expenses and problems caused by poor material performance.

\section{Milestones:}

1. Development of a knowledge base and heuristic rules 36 months.

2. Development of an expert system - 48 months. 


\section{RNS-5}

\section{RESEARCE PLANNING FOR HIGE TECBNOLOGY FEDERAL OFEICE BOILDINGS}

\section{RESEARCE NEEDS STATEHENT}

\section{RESEARCB ISSOE :}

Expert system for selecting fenestration/envelope basec on consideration of thermal and acoustic performance of window systems

Building Systems Involved:

Eenestration/Envelope

Problem Statement:

The thermal integrity of glazing may be achieved without any significant increase in the degree of noise insulation. However, the thermal performance and acoustic characteristics of window systems may be integrated to achieve both energy efficiency and noise isolation requirements. Expert systems have tre potential for effectively assisting in making high quality cecisions zalative to the selection and design of fenestration systems.

Technical Approach:

The knowledge of experts in making decisions about thermal and acoustic design criteria for glazing will be recordec in ire form of a knowledge base and an heuristic approach for aecision making developed.

\section{Product:}

An expert system for computer-aided thermal/acousticai design of fenestration systems will be produced.

Implementation:

The system will be implemented through its use in selection c $c$ fenestration systems having project specific compatibie anci conplementary acoustical and thermal performance.

\section{Impact:}

Development and use of an expert system for the seiectior. anci design of fenestration systems will result in cost eziect: $\because e$ thermal and acoustical performance of fenestratior.

\section{Milestones:}

1. Develop knowledge base and heuristic ruies - 36 nonin.

2. Develog expert system - 48 montis. 


\section{RESEARCE NEEDS STATEMENT}

\section{RESEARCB ISSOE:}

Glazing and antireflective coatings

Building Systems Involved:

Windows

Problem Statement:

Significant heat gains can be obtained through effective use of southern exposure windows. Glass, combined with antireflective materials or coatings, has performed well according to manufacturers. But other glazing materials, such as plastics, could offer cost, weight and optical benefits over glass and could be formed with antireflective materials (as opposed to the add-on materials used with glass). A barrier to their use is lack of test methods to help assure durability.

\section{Technical Approacb:}

The approach would involve 1) identifying performance requirements, 2) developing test methods, based upon laboratory studies, to measure performance according to the requirements, and 3 ) assisting in implementing the use of the methods by interactions with the building community and standards setting organizations.

\section{Product:}

Report(s) presenting the results and the proposed test methods will be produced.

\section{Implementation:}

Presentations at conferences, publication of results, interaction with standards setting organizations.

\section{Impast:}

The test methods will help provide for increased use of substitute materials.

\section{Milestones:}

1. Identify performance requirements - 3 months.

2. Report with preliminary test methods - 12 months.

3. Report with final test methods - 30 months. 


\section{RESEARCE PLANNING FOR BIGH TECENOLOGY FEDERAL OPFICE BOILDINGS}

\section{RESEARCE NEEDS STATEMENT}

\section{RESEARCB ISSOE:}

Expert system for selecting roofing materials based on consideration of design and weather conditions. This system will be a prototype system which demonstrates the benefits of developing and using expert systems.

Building Systems Involved:

Roofing Systems

Problem Statement:

Often sufficient information is not readily available on materials performance and durability to make decisions on selecting durable roofing materials. Expert systems can be potentially effective in making high quality decisions in the selection of durable roofing materials. Expert systems are computez prograns which mimic the reasoning of human experts.

Technical Approach:

The knowledge of experts on the performance and durability of roofing materials will be recorded in the form of a knowledge base and heuristic rules. They will be encoded in a conputer program which can give recommendations at or near the level of human experts thus facilitating and improving the selecticn process.

Product:

An expert system for selecting roofing materials will be developed and its usefulness demonstrated.

Implementation:

The expert system will be implemented through its uss in selecting roofing materials.

Impact:

Development and use of an expert system will result in the inproved selection of roofing materials, thereby recucirg expenses and problems caused by poor material performance.

Milestones:

1

36 months.

Development of a knowledge bese and heuzistid ruies -

2. Development of an expert system - 48 monzhs. 
RNS-8

\section{RESEARCE PLANNING POR BIGB TECENOLOGY PEDERAL ORFICE BOIIDINGS}

\section{RESEARCE NEEDS STATEMENT}

RESEARCE ISSOE:

Database on material performance

Building systems Involved:

Major building materials, e.g., coatings and paints, roofing materials, concrete and masonry, and metals exposed to weathering

Problem statement:

Well-documented information on the in-service performances of building materials is rarely available. The availability of such information would aid in the selection of more cost-effective materials. Computer databases need to be established to store the information, thereby making it available to those responsible for making decisions on material selection.

\section{Technical Approach:}

1. Identify the properties, characteristics, and features of building materials which, when documented, will indicate the performances of specific building materials.

2. Develop recommendations on evaluation methods.

3. Select and format database systems.

\section{Product:}

A methodology for establishing a database on the performances of building materials will be developed.

\section{Implementation:}

The methodology will be implemented by using it to document the performance of major building materiais in "high-tech" Eederal office buildings.

\section{Impact:}

A significant cost savings will result because use of the database will assist in selecting materials of proven performance. Also, the database can aid in the making of decisions regarding whether a material should be repaired or replaced.

\section{Milestones:}

1. Ijentification of properties, characteristics and features of building materials which should be documented - 3 months. 
2. Develop recommendations on material evaluation methods 6 months.

3. Select and format database - 12 months. 
RNS-9

\section{RESEARCB PLANNING FOR BIGE TECENOLOGY FEDERAL OPFICE BOILDINGS}

\section{RESEARCB NEEDS STATEMENT}

\section{RESEARCE ISSOE:}

Substitute materials for building materials containing asbestos

Building Systems Involved:

Flooring and Building Envelope

Problem Statement:

Asbestos fibers have been incorporated in a variety of building materials.

The literature contains extensive documentation addressing potential health effects associated with exposure to airborne asbestos fibers. (Since NBS has no medical expertise, there has been no attempt to evaluate this documentation.) Some of the products containing asbestos are given in the attached table. If properly identified and selected, substitute materials can be used in building construction. The substitute materials should be the technical equivalent of the building materials containing asbestos.

Technical Approach:

1. Identify asbestos-containing building materials used in the construction of GSA builaings.

2. Establish performance requirements for substitute materials.

3. Develop recommendations for selecting substitute materials based on performance requirements.

Product:

Report giving recommendations for selecting substitute building materials will be developed.

Implementation:

Results of the study will be published.

\section{Impact:}

A technical basis will be developed to assist GSA in selecting building materials which do not contain asbestos.

Milestones:

1. Identify asbestos-containing building materials used in GSA buildings - 6 months.

2. Develop performance requirements for substitute materials 12 months. 
3. Report giving recommendations for selecting substitute materials - 18 months. 
Taken from "Guidelines for Assessment and Abatement of Asbestos-Containing Materials in Buldings," NBSIR 83-2688, 1983

Table 1.3 Nonfriable Matrix Bonded Composite Products Containing Asbestos 1 , 2 f

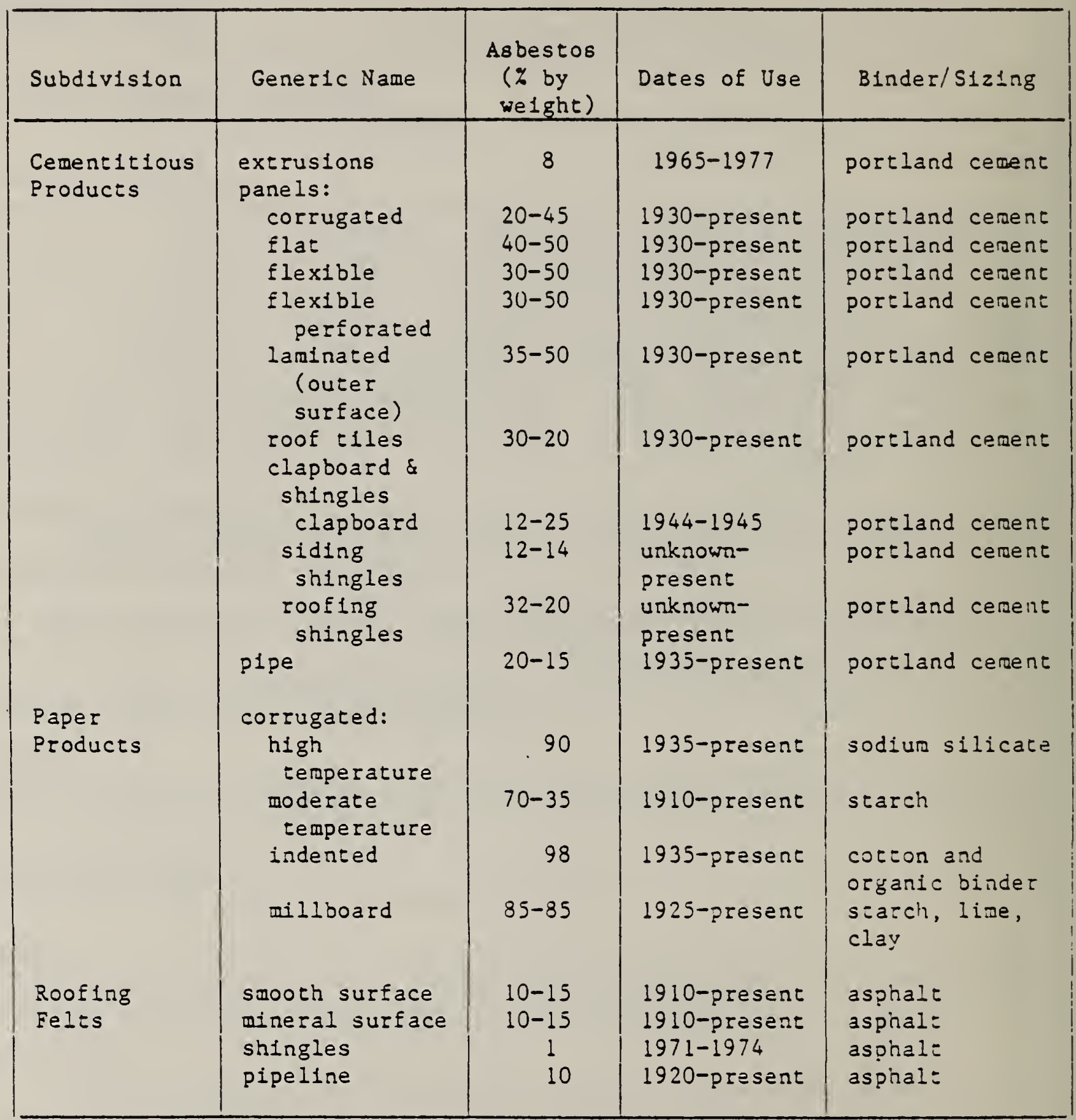

1/ Table was taken from reference [5].

2/ The Navy prohibits use of these products when acceptable nonasbestoscontaining substitutes have been identified. 
Table 1.3 (continued)

\begin{tabular}{|c|c|c|c|c|}
\hline Subdivision & Generic Name & $\begin{array}{c}\text { Asbestos } \\
\text { (\% by } \\
\text { we1gnt) }\end{array}$ & Dates of Use & Binde=/Siz1ng \\
\hline $\begin{array}{l}\text { Asbestos- } \\
\text { Containing } \\
\text { Compounds }\end{array}$ & $\begin{array}{l}\text { caulking putties } \\
\text { adhesive (cold } \\
\text { applied) } \\
\text { joint compound } \\
\text { roofing asphalt } \\
\text { mastics } \\
\text { asphalt tile } \\
\text { cement }\end{array}$ & $\begin{array}{r}30 \\
5-25 \\
5 \\
5-25 \\
13-25\end{array}$ & $\begin{array}{l}\text { 1930-present } \\
1945 \text {-present } \\
1945-1975 \\
\text { unknown- } \\
\text { present } \\
1920 \text {-present } \\
1959 \text {-present }\end{array}$ & $\begin{array}{l}\text { linseed oil } \\
\text { asphal: } \\
\text { asphal: } \\
\text { asphal: } \\
\text { asphal: } \\
\text { asphale }\end{array}$ \\
\hline . & $\begin{array}{l}\text { roof putty } \\
\text { plaster/stucco } \\
\text { spackles } \\
\text { sealants } \\
\text { fire/water } \\
\text { cement, } \\
\text { insulation } \\
\text { cement, } \\
\text { finishing } \\
\text { cement, magnesia }\end{array}$ & $\begin{array}{r}50-55 \\
20-100 \\
55 \\
15\end{array}$ & $\begin{array}{l}1935-p \text { resent } \\
1900-1973 \\
1920-1973 \\
1926-1950\end{array}$ & $\begin{array}{l}\text { asphalt } \\
\text { portland cerent } \\
\text { starch, casein, } \\
\text { synthetic } \\
\text { resins } \\
\text { caster oil or } \\
\text { polyisobutylene } \\
\text { clay } \\
\text { clay } \\
\text { dagnesiun } \\
\text { carbonaze }\end{array}$ \\
\hline $\begin{array}{l}\text { Asbestos } \\
\text { Ebony } \\
\text { Products }\end{array}$ & & 50 & 1930-present & porkiand cenent \\
\hline $\begin{array}{l}\text { Flooring } \\
\text { Ille and } \\
\text { Sheet Goods }\end{array}$ & $\begin{array}{l}\text { vinyl/asbestos } \\
\text { tile } \\
\text { asphalt/asbestos } \\
\text { tile } \\
\text { sheet goods/ } \\
\text { resilient sheet }\end{array}$ & $\begin{array}{r}21 \\
26-33 \\
30\end{array}$ & $\begin{array}{l}1950-p r e s e n t \\
1920-p r a s e n t \\
1950 \text {-prent }\end{array}$ & $\begin{array}{l}\text { po? } \because(\because i n y-1)- \\
\text { chlorije } \\
\text { asphal= } \\
\text { dry oils }\end{array}$ \\
\hline Wallcovering & vinyl wallpaper & $6-8$ & $\begin{array}{l}\text { unknown- } \\
\text { present }\end{array}$ & -- \\
\hline $\begin{array}{l}\text { Paints and } \\
\text { Coatings }\end{array}$ & $\begin{array}{l}\text { roof coating } \\
\text { aif tight }\end{array}$ & $\begin{array}{r}4-7 \\
15\end{array}$ & $\begin{array}{l}\text { 1900-prasent } \\
\text { 1940-prysent }\end{array}$ & $\begin{array}{l}\text { aspinaz= } \\
\text { aspiral: }\end{array}$ \\
\hline
\end{tabular}




\section{RNS-10 \\ RESEARCE PLANNING POR BIGE TECBNOLOGY PEDERAL OPPICE BOILDINGS}

\section{RESEARCH NEEDS STATEMENT}

RESEARCB NEEDS:

Teleconferencing: acoustic criteria

Building Systems Involved:

Teleconferencing Facilities

Problem Statement:

Teleconferencing facilities offer the potential to increase building users' productivity by allowing direct communication without the need to assemble staff at one location at a scheduled time. Moreover, the success of teleconferencing is dependent upon adequate acoustic environment in the conference room. Acoustic criteria for teleconferencing rooms must be developed and integrated with teleconferencing system design.

Technical Approach:

Develop acoustic criteria for teleconferencing facilities based upon a literature search and a review of existing facilities/systems characteristics.

Product:

Acoustic criteria for the design of teleconferencing rooms will be developed.

Implementation:

The criteria will be implemented through the design of teleconferencing facilities, publications, presentation to the building community and interaction with standard setting organizations.

Milestones:

Develop acoustic criteria for the conferencing facilities - 36 months. 


\section{RNS- 11}

\section{RESEARCE PLANNING FOR HIGE TECENOLOGY FEDERAL OFFICE BUILDINGS}

\section{RESEARCH NEEDS STATEAHENT}

\section{RESEARCE ISSUE :}

HVAC systen data base and operating manual

Building Systems Involved:

HVIAC (including E:!CS)

\section{Problem Statement:}

There are many variables which change a ouiluing's therkal loej. These include weather variables (temperature, humicit?, $\equiv$ j $^{\prime}=$, wind, ground aicitude, etc.), bliloing construction (.as , thermal insulation, location, oriertation, geonetricai arrangements, ecc.), and user factors (usage, lozist: lojeing

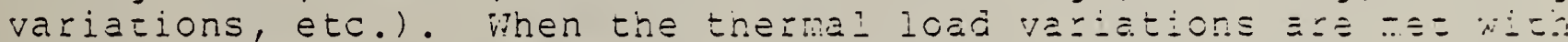
SVAC system changes (temperature, flov rate, a syster efficiency, etc.), it is very jificht for tie viliging operators to tune the systems to their optimun condizisn $1: 2$ terns of energy consumption, equipment naintenance, $\equiv$ oce conditions, etc.). Therefore, an operating ranial co osti...z IVAC system performance is needed.

Technical Approach:

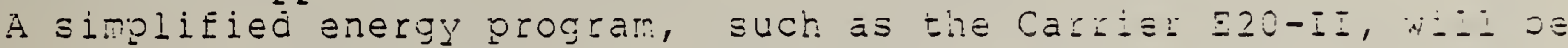
usec to calculate building energy consung=ion. Pre buizir.

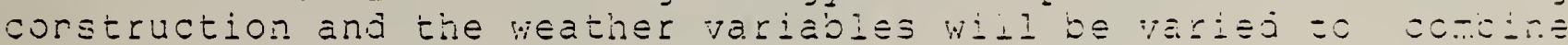

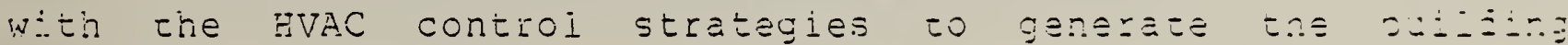
performance data base.

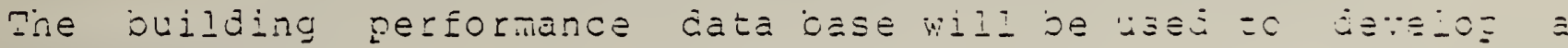

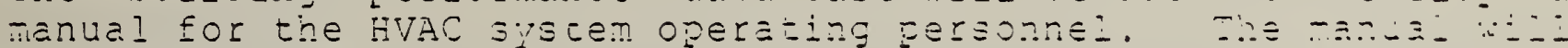

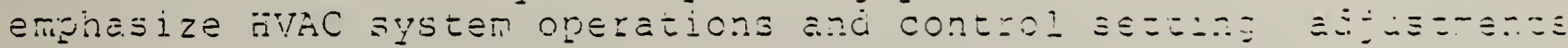

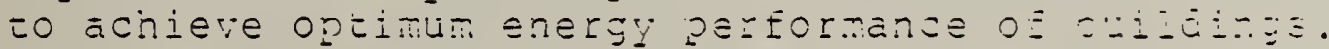

\section{Product:}

A manual for operating personnez on on:inzin; perfornance rill ze proüuces.

Implementation:

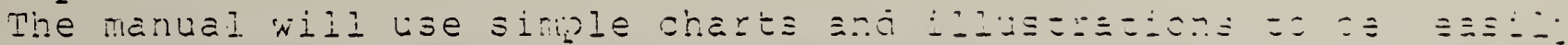

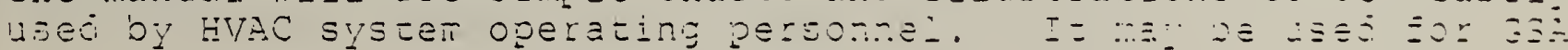
builingos and other governtenc and a:-

Impact:

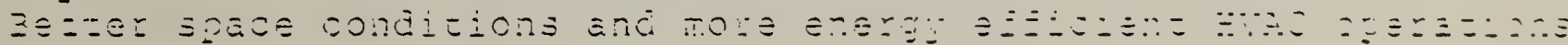

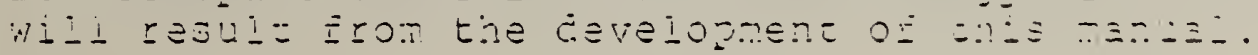


Milestones:

1. Generate the building performance data base - 6 months.

2. Manual for HVAC system operating personnel - 12 months. 
RNS-12

\section{RESEARCE PLANNING FOR BIGB TECBNOLOGY PEDERAL OPFICE BOIIDINGS}

\section{RESEARCB NEEDS STATEMENT}

\section{RESEARCE ISSUE:}

Improve variable air volume (VAV) system controls

Building System Involved:

HVAC Systems

Problem Statement:

The VAV system has been generally recognized as the most energy efficient air handling system. In actual installation, there are numerous problems associated with the system, such as not neetir:g zone load variations, poor system pressure responses, noise, and improper space pressure balance. Although some of these problems may be traced to inadequate engineering during design and construction, guidelines for VAV system design centered around system controls will assist the designers in simplifying the design procedures and improve the system performance.

\section{Technical Approach:}

VAV systems will be categorized by the builing load characteristics, air distribution system arrangements and VAV system types. In each group, fan pressure variations in the entire duct system, as well as the pressure in the builaing, will be investigated in detail. Guidelines of fan systems and space pressure controls will be developed for each group.

Product:

A report on improving VAV system controls will be producec.

\section{Implementation:}

The guideline on improving VAV system controls will be arailable to GSA design engineers and $A / \bar{E}$ Iirms engaging in GVAC syster. designs. The obstacle of selecting VAV systems will be lessened.

\section{Impact:}

More acceptance of VAV systems can be expected anc bettez इzace environment control can be achieved.

\section{Milestones:}

1. Investigate possible VAV systems by builings - 3 monkns.

2. Generate pressure data - 6 months.

3. Report on improving VAV system controls - 12 montis. 
RNS-13

RESEARCE PLANNING FOR BIGE TECBNOLOGI PEDERAL OPFICE BOILDINGS

\section{RESEARCE NEEDS STATEMENT}

\section{RESEARCB ISSUE:}

outside air management and indoor air quality

Building Systems Involved:

GVAC (including EMCS), Fire Protection

Problem statement:

A large part of building energy consumption is for treating the outside air which is delivered to occupied spaces as fresh air. A detector, such as for $\mathrm{CO}_{2}$, which senses the occupant load may be used to control the amount of outside air to be admitted to the building. Thus, a large amount of energy may be saved.

\section{Technical Approach:}

1. A reliable occupant sensing system $\left(\mathrm{CO}_{2}\right.$ or other parameters) will be researched and developed.

2. The method and logic of integrating the sensing system into the HVAC control system and/or building management system will be developed. Included will be locations of sensors, damper operations to comply with occupant and building needs, integration with other EMC algorithms (such as economy cycles), and fire/smoke management.

Product:

A report on outside air management using occupant-related sensors will be produced.

\section{Implementation:}

The results of this investigation will enable GsA to modify its policy on outside air management. The building outside air management may also be implemented through ASGRAE and building code authorities.

\section{Impact:}

Considerable amount of building energy use may be eliminated.

Milestones:

1. Investigate occupant sensing system - 6 montis.

2. Develop the logic and method for implementing control systems - 9 months.

3. Report results - 12 months. 
RNS-14

\title{
RESEARCE PLANNING FOR BIGE TECBNOLOGY FEDERAL OFFICE BOILDINGS
}

\author{
RESEARCE NEEDS STATEMENT
}

\section{RESEARCB ISSOE:}

Postoccupancy evaluation of computer-based building operazing systems

Building Systems Involved:

Computer-Based Systems

Problem Statement:

Many computer-based systems are now in place in Federal and private sector buildings, but no systematic effort has been made to evaluate the potential wealth of experience that has been accumulated by building users. This experience would constitute a major resource for those making design decisions concerning nei buildings and the retrofitting of the existing building stock.

Technical Approach:

A sample of buildings, building systems, and subsystems should be examined by an appropriate interdisciplinary research tean to determine what "has worked" and what "has not worked" and why. The systems examined should encompass energy managenent, operational, safety and security and the integration of these various systems. Interviews should be conducted with users, designers and facility managers, and appropriate physical measurexents should be made to quantify findings.

Product:

A handbook will be produced, suggesting approaches for the cesign and implementation of computer-based builing systens and subsystems.

Implementation:

The handbook will be distributed to GSA/PBS personnel E0: EL:the: distribution to the design community serving cie Eacezal Government.

\section{Impact:}

More effective use will be made of the injoznation availabis concerning computer-based systems in buildings - - cesulting in higher productivity and cost savings to tie Eederji corernment.

Milestones:

1. Development of detailed research pian - 12 nontis.

2. Completion of handbook - 36 months. 


\section{RNS-15 \\ RESEARCA PLANNING POR BIGE TECENOLOGY PEDERAL OPFICE BOIIDINGS}

\section{RESEARCB NEEDS STATEMENT}

\section{RESEARCB ISSUE:}

Simulation of a building circulation system to be used as a support utility to the fire safety and security systems

Building Systems Involved:

Fire safety and security

Problem Statement:

Tactical responses to emergency incidents are generally infrequent throughout the operating life of most buildings. As a result, the building operators and guard force do not have an opportunity to quickly and inexpensively explore the many types of responses that can be employed for various emergency incidents. Therefore, there is a need for an analytical tool that can quickly develop and communicate tactical responses to a great many types and severities of fire safety and security incidents in a building operator training mode.

Technical Approach:

1. Determine the extents of the fire safety and security systems (detection and communication devices and response strategy).

2. Develop a model of the facility of concern using a high level simulation language.

3. Validate and test the model.

4. Document the model and train building operators in its use.

Product:

1. A fire safety and security incident simulation and response recommendation model.

2. Model documentation.

Implementation:

The model will be installed as an on-line utility for the building fire, security, and/or integrated management system.

Impact:

Provides fire safety and security personnel with the neans to describe an incident and receive optional tactical responses that may be employed. 


\section{Milestones:}

1. Develop a modeling approach - 9 months.

2. Validate and test the model - 12 months.

3. Document and report the model - 24 months. 


\subsection{SOMMARY}

This report has briefly explained the high-tech design approach being developed by PBS. In addition, the objective and scope of the potential NBS technical support to PBS have been described. The results of the NBS support were presented in the form of functional programming statements and research needs statements.

The functional programming statements were organized according to the categories of the GSA design directives found in design programs. Although no statements were developed for categories one, two and five (see page 3), seven statements were developed for building infrastructure, three statements were developed for building enclosures, and seven statements were developed for building systems.

The research needs statements were also organized to the extent possible, according to the design directives categories. No statements were developed for categories one and two, however, two statements were developed for building infrastructure, six statements were developed for building enclosures, one statement was developed for space allocation, and five statements were developed for building systems. 
NBS.114A \&EV. $=$-AC

\begin{tabular}{l|l} 
U.S. JEPT. OE COMM. & 1. PUBLICATION OR
\end{tabular} REPORT NO.

BIBLIOGRAPHIC DATA

SHEET, Sez in Strucion SI

4. TITLE AND SUETITLE

Functional Programming/Research Planning for High Technology Federal Office Builicings

5. AUTHOR(S) G.E. Turner, J.R. CTifton, J.Y. KaO, G.E. Reliy, L.N. ilasiers, i.t. itsum, A.I. Rubin, S.T. Wu, S.L. Yaniv

6. PERFORMING ORGANIZATION (If joint or other than N8S, see inscructions)

HATIOHAL BUREAU OF STANOARDS

DEPARTHENT OF COMHERCE

WASHINGTON, O.C. 20234

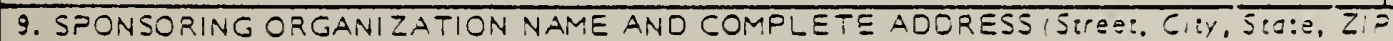

Public Buildings Service

General Services Administration

Washington, OC 20405

10. SUPPLEMENTARY NOTES

- Document describes a comouter program; SF-185, FIPS Software SuTmary, is a::z=nz=.

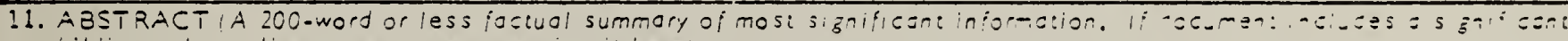
bibliogrophy or literature survey. mention it herel

The General Services Administration (GSA), Dublic Buildings se:vice (PBS) is engaged in the development of a new oesign approach for Federal buildings referred to as "nigh technology" (high-tech). The approach emphasizes the consideration of now, emerging and innovative uses of existing technology apolications in building system design, construction and operazion. In ordez to develop design programs for high-tech building projects, there is a need for PBS to identify progranming issues that address new, emerging and innovative uses of existing zechno:ogies, and there is a need for PBS to deveiop a olan o E Iesearch in support of its high-tech design approach. Uncez a nenorandud of understanding with GSA, the National BuzeaL o: Standarjs' (NBS), Center for Building Tecinology (CST) assisted ?3S by providing technical support through the devi:oznen: o: prog:anming issues and research needs for high-tech ojzice builings. The programing issues and research needs deveiosec by represent the identification of programming and reseszch Eopics to be considered by GSA during its progran=ing and reseazch planning activities.

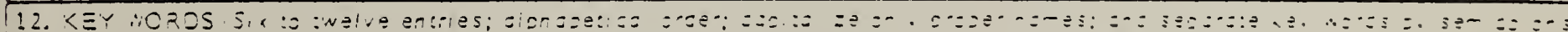

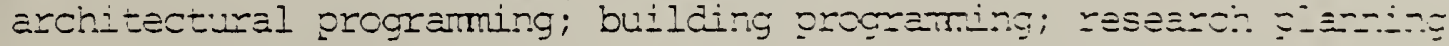

13. AVAULBLILTY

- Unlimited

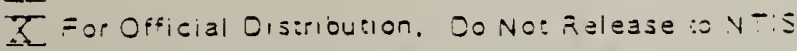

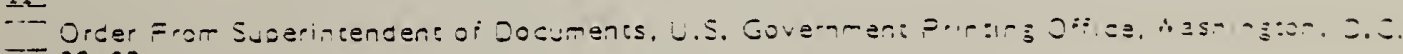
20402.

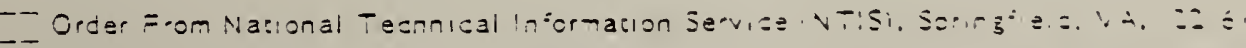

$\therefore 4.8=$

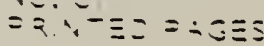




